00-preliminares.qxd 11/09/2010 5:01 PEgina 1 
00-preliminares.qxd 11/09/2010 5:01 PÆgina 2

Tiempo emulado

Historia de América y España

13

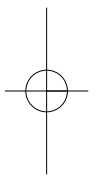


Ana de Zaballa Beascoechea (ed.)

\section{Los indios, el Derecho Canónico y la justicia eclesiástica en la América \\ Hispana virreinal}


Este libro forma parte del proyecto de investigación «Creencias, usos y costumbres indígenas y la justicia eclesiástica en la América virreinal», subvencionado por el Ministerio de Ciencia y Tecnología de España.

Derechos reservados

(C) Iberoamericana, 2010

Amor de Dios, 1 - E-28014 Madrid

Tel.: +34914293522

Fax: +34914295397

info@iberoamericanalibros.com

www.ibero-americana.net

(C) Vervuert, 2010

Elisabethenstr. 3-9 - D-60594 Frankfurt am Main

Tel.: +49695974617

Fax: +49695978743

info@iberoamericanalibros.com

www.ibero-americana.net

ISBN 978-84-8489-519-0 (Iberoamericana)

ISBN 978-3-86527-575-2 (Vervuert)

Depósito Legal:

Cubierta:

Este libro está impreso íntegramente en papel ecológico sin cloro. 


\section{ÍNDICE}

Prólogo por Ana de Zaballa Beascoechea $\ldots \ldots \ldots \ldots \ldots \ldots \ldots . . \ldots$

INTRODUCCIÓN por Jorge Trasloheros . . . . . . . . . . . . . . . . . . 11

\section{LOS INDIOS Y EL DERECHO CANÓNICO}

Thomas Duve

La jurisdicción eclesiástica sobre los indígenas y el trasfondo del

derecho canónico universal ............................

Ana de Zaballa Beascoechea

Reflexiones en torno a la recepción del derecho eclesiástico por

los indígenas de la Nueva España ....................... $\quad 45$

Alberto Carrillo Cázares

La procuración de justicia a la población indígena en el Concilio Tercero Provincial Mexicano (1585) .......................

Luis Martínez Ferrer

La defensa de la libertad de indios y negros para contraer

matrimonio en el Tercer Concilio Mexicano (1585)

\section{VISITAS ECLESIÁSTICAS Y EXTIRPACIÓN DE IDOLATRÍAS}

Macarena Cordero Fernández

Formación de una institución: las visitas de idolatrías ...

Juan Carlos García Cabrera

El juicio de capitulos de los indios contra Francisco de Ávila (1607-1610). Reflexiones sobre el proceso judicial ................ 
Pedro M. Guibovich Pérez

Visitas eclesiásticas y extirpación de la idolatría en la diócesis de Lima en la segunda mitad del siglo XVII ........................

\section{LOS INDIOS ANTE LOS FOROS DE JUSTICIA ECLESIÁSTICA}

John Charles

Felipe Guaman Poma en los foros de la justicia eclesiástica ........ 201

Magnus Lundberg

Justicia eclesiástica en un escenario local novohispano: Peticiones

indigenas de Ixcateopan en el siglo XVII ..................

SOBRE LOS AUTORES 


\section{Prólogo}

En febrero de 2009 tuvo lugar el Seminario Internacional «Iglesia, justicia y población indígena en la América virreinal». El Seminario forma parte de un proyecto de investigación I+D del Ministerio de Ciencia e Innovación de España, que bajo el título de Creencias, usos $y$ costumbres indígenas y la Iglesia en la América virreinal lleva tres años trabajando sobre la actuación de los tribunales eclesiásticos y su relación con la población indígena. Este libro reúne los trabajos y discusiones del Seminario celebrado dentro del citado proyecto.

El objetivo de estas investigaciones es profundizar en el estudio de las audiencias eclesiásticas en su relación con los naturales, desde diferentes ópticas y para ello la concurrencia, en un mismo foro de discusión, de especialistas procedentes de la historia del Derecho indiano, de la historia de la Iglesia y de la historia de la sociedad colonial; así como la coincidencia de investigadores de países con diferentes patrimonios historiográficos, México, Perú, Chile, Estados Unidos, Alemania, Suecia, Italia y España. Esto ha enriquecido la visión y los planteamientos de estudio de las audiencias eclesiásticas, que hasta el momento se ha centrado casi exclusivamente en los procesos por idolatrías y las campañas de extirpación. El libro que tenemos entre manos es una muestra de la variedad de asuntos en los que actuó el tribunal del obispado en relación a los indígenas y la riqueza que ofrece esta documentación para profundizar en la realidad social, cultural, vida cotidiana, etc.

La primera parte de esta monografía se centra en la relación entre Derecho y Derecho Canónico indiano y los naturales. Los dos prime- 
ros capítulos, del Dr. Duve y la Dra. de Zaballa nos remiten al derecho canónico desde un punto de vista general, ya sea por su naturaleza, en el primer caso o por el proceso de recepción en el segundo. El profesor Thomas Duve, de la Pontificia Universidad Católica de Argentina, y especialista en derecho canónico indiano, diserta sobre las fuentes en las que se apoya la jurisdicción eclesiástica en los siglos XVI y XVII en las Indias. Como sucede en las demás instituciones indianas en su traslado al Nuevo Mundo, este marco normativo fue modificado por la legislación posterior y particular, y fue interpretado dentro de los paradigmas culturales de cada tiempo y región. Esto produjo una gran variedad y amplitud de prácticas. Sin embargo, el Derecho Canónico universal no dejó de tener su importancia para estas prácticas, como el ámbito o luz bajo la que debían ser leídas. Como resultado del debate que se llevaba a cabo entre los canonistas y juristas seculares sobre la competencia jurisdiccional de los obispos respecto de las personas miserables - y su aplicación a los indígenas-, se puso de manifiesto el uso de las fuentes y, al tiempo, las particularidades indianas.

La profesora De Zaballa presenta en su estudio el conocimiento y abundante uso del Derecho por parte de los indios. No sólo del Derecho secular, como hasta ahora se había demostrado, sino también del Derecho eclesiástico y la recepción del mismo. Queda manifiesta la familiaridad y la capacidad indígena de desenvolvimiento en los foros de justicia eclesiástica. En el ámbito de historiadores del derecho, el concepto recepción ha generado una apertura a nuevas e interesantes reflexiones en la línea en que se plantea en este trabajo.

Le siguen dos capítulos sobre el Tercer Concilio Mexicano y la población indígena.

Respecto de los concilios el Dr. Carrillo enfoca su exposición hacia uno de los nuevos cauces de estudio sobre la administración de justicia a la población indígena en el ámbito de la Iglesia indiana: el cauce que se abre en los debates y decisiones de los concilios provinciales de México y el Perú, realizados en el siglo XVI. Trata específicamente de tres de las ocho grandes consultas que el Concilio Tercero Provincial Mexicano de 1585, sometió a consideración de la asamblea episcopal y de sus asesores teólogos y juristas: la injusticia de la guerra a los indios chichimecas, el problema laboral de trabajo conscripto a que era sometida la población indígena por el sistema de repartimientos; y la referente a la economía y el comercio, corrompidos por la usura y la 
sed de lucro. También en el marco del Tercer Concilio provincial, el Dr. Luís Martínez Ferrer de la Universitá della Santa Croce (Roma), presenta el proceso de elaboración del texto sobre la libertad para contraer matrimonio de indios y negros. Recorre el desarrollo del texto desde la propuesta de Pedro de Hortigosa hasta la definición de los decretos conciliares.

La tercera parte se centra en las visitas de idolatrías llevadas a cabo en el virreinato del Perú y la controversia que sobre este tema está presente en la historiografía actual. La Profesora Macarena Cordero de la Universidad Adolfo Ibáñez de Santiago de Chile, trata de demostrar que las visitas de idolatrías practicadas en la diócesis de Lima durante el siglo XVII constituyeron una institución de derecho canónico indiano. Para ello analiza su formación, desarrollo y evolución, considerando los diversos factores y situaciones que contribuyeron a darles forma, sistematizarlas y regularlas, para así finalmente institucionalizarse; una institución propia de Lima, con características que la distinguen de otras instituciones como las visitas pastorales o la Inquisición.

El Dr. Guibovich entra en discusión con el capítulo anterior y amplía la visión historiográfica, pues analiza las visitas de idolatrías, que denomina «extirpación de la idolatría», pero en su relación con las visitas eclesiásticas ordinarias, concretamente las que tuvieron lugar en el arzobispado de Lima durante el siglo XVII. Guibovich sostiene que la extirpación debe considerarse, en el marco de la historia institucional eclesiástica, como una parte del proceso de la visita eclesiástica y no como un proceso aislado.

Desde hace décadas cierta historiografía ha consagrado la visión del arzobispado de Lima como el escenario de permanentes campañas destinadas a reprimir las manifestaciones de la religiosidad nativa indígena. No cabe duda que las llamadas «campañas de extirpación» fueron acontecimientos centrales en la historia de la diócesis limeña. Sin embargo, tales campañas muchas veces formaron parte de la visita eclesiástica ordinaria y los extirpadores fueron visitadores con amplias atribuciones que les conferían autoridad para fiscalizar el funcionamiento de la doctrina y el comportamiento de curas y feligreses. Para ilustrar su hipótesis el Dr. Guibovich se sirve de un caso emblemático: el del clérigo Juan Sarmiento de Vivero, activo como extirpador, pero sobre todo como visitador, a fines de la década de 1650. 
La última parte se dedica a estudios de caso. El Dr. Magnus Lundberg, revisa varios casos con vistas a investigar el papel del juzgado eclesiástico en los conflictos entre curas y feligreses indígenas en el México virreinal. Con el fin de hacer un análisis detallado del funcionamiento del juzgado en un contexto local, examina el caso del pueblo de Ixcateopan, actual estado de Guerrero, durante la primera mitad del siglo XVII. En particular analiza el tipo de acusaciones que fueron presentadas por los peticionarios y los testigos indígenas.

Por último, el Dr. John Charles de la universidad de Tulane, expone, a través de la obra de Guaman Poma de Ayala, la historia del traslado y aplicación de las prácticas jurídicas hispanas al sector indígena peruano de los siglos XVI y XVII. Analiza el discurso jurídico-canónico de la famosa crónica, para comprender cómo el cronista utiliza el sistema legal, y especialmente lo referido al derecho eclesiástico, para denunciar a los sacerdotes.

Nos ofrece el análisis de causas de capítulos, o pleitos de los tribunales eclesiásticos, que los caciques y otros dirigentes indígenas presentaron contra los curas de indios para combatir los abusos del clero en las comunidades andinas locales. Queda patente, el amplio conocimiento del Derecho Canónico y su uso por parte de los naturales peruanos de los siglos XVI y XVII.

Se completa así un breve recorrido, desde el Derecho Canónico y su recepción, las discusiones jurídicas en el Tercer Concilio Provincial y la aplicación del Derecho eclesiástico a casos concretos en ambos virreinatos.

Ana de Zaballa Beascoechea 


\section{INTRODUCCIÓN}

\section{Los indios, el Derecho Canónico y la justicia eclesiástica: las razones y el drama de una historia}

\section{Los indios, El Derecho CanÓNiCo y los Foros de JUSTICIA}

El libro que el lector tiene en sus manos es producto del trabajo de un grupo de académicos que coordinan sus esfuerzos bajo el liderazgo de la Dra. Ana de Zaballa ${ }^{1}$. Se trata de una comunidad internacional en la que nos hemos propuesto investigar y reflexionar en torno a la muy estrecha relación que se estableció entre los indios, el Derecho Canónico y los diversos foros de justicia en materia religiosa que existieron en la Hispanoamérica virreinal. Buscamos enriquecer el conocimiento sobre este pasado por medio de la discusión y el análisis, siempre a partir de las fuentes, por lo que el lector no encontrará un planteamiento único del fenómeno estudiado, sino una multiplicidad de voces que se dejan interpelar por una realidad cuya riqueza es tal que sorprende y ensancha los límites de nuestra razón. En esta obra se podrán encontrar reflexiones sobre los dos pilares, los dos horizontes de comprensión, las dos metáforas sobre las cuales se levantó la Monarquía de España — como parte de la cultura occidental—y que, por desgracia, suelen pasarse por alto con lo que se limita la compren-

1. Remito a dos libros anteriores: Ana de Zaballa (Coord.), Nuevas perspectivas sobre el castigo de la heterodoxia indígena en la Nueva España: siglos XVI-XVIII, Bilbao, Universidad del País Vasco, 2005; y, Jorge Traslosheros y Ana de Zaballa (Coords.), Los indios ante los foros de justicia religiosa en la Hispanoamérica virreinal, México, Universidad Nacional Autónoma de México, Instituto de Investigaciones Históricas, 2010. 
sión de elementos sustanciales de aquella realidad. Estos pilares son el Derecho y la religión, en este caso la católica ${ }^{2}$.

El libro ha sido dividido en tres partes: la primera, estudia la relación de los indios con el Derecho Canónico; la segunda, discute la naturaleza de las visitas episcopales en materia de indios, con especial énfasis en el problema de «las idolatrías» en el Perú; y, la tercera, explora la relación con los tribunales eclesiásticos ordinarios, también llamados audiencias eclesiásticas y provisoratos.

En la primera parte se discute la milenaria tradición del Derecho Canónico en asuntos muy concretos como puede ser la definición jurídica de la persona «indio», la forma en que los naturales aprendieron a valerse de ella, así como ciertas peculiaridades del Tercer Concilio Provincial Mexicano. En su conjunto, se explora el complejo proceso que podemos identificar como recepción del Derecho Canónico lo que involucra su arribo, adaptación, modificación y la construcción de una propuesta desde las Indias. Se estudia la recepción de un Derecho de inspiración y finalidad religiosa que se nutre así del rico suelo de la tradición, como de la realidad social a la cual pretendió servir y ordenar. La riqueza de este proceso se aprecia, asimismo, en la segunda y tercera parte de la obra dedicadas a la interacción entre los foros de justicia y los indios, ya se trate de las visitas episcopales, del foro de la conciencia, de los conflictos presentados ante los tribunales eclesiásticos ordinarios o de las profundas reflexiones que sobre la justicia, la religión y la sociedad nos legó aquel «peregrino de los Andes» Felipe Guamán Poma de Ayala.

Estos trabajos dan cuenta de la riqueza y el dinamismo del Derecho Canónico en sus distintas formas: sea consuetudinaria, que es la tradición en su más profundo sentido, como la voz viva de los muertos y que debe entenderse en oposición al tradicionalismo que es la voz muerta de los vivos; la jurisprudencial, que es la voz de los tribunales en donde se dirime y valida el Derecho; la doctrinaria que se for-

2. Remito a las obras de Harold Berman, La formación de la tradición jurídica de Occidente, México, Fondo de Cultura Económica, 1996; Law and Revolution II. The Impacts of the Protestant Reformations on the Western Legal Tradition, Cambridge, Harvard University Press, 2003. Igualmente, Paolo Grossi, Derecho, sociedad, Estado, México, Escuela Libre de Derecho, El Colegio de Michoacán, UMSNH, 2004; El orden jurídico medieval, Madrid, Marcial Pons, 1996. 
mula, se debate y propone por los jurisperitos tan íntimamente relacionados con los tribunales y las universidades; la legal en donde se despliega su riqueza a través de concilios, sínodos, ordenanzas episcopales, etc. Todas, en relación con el Derecho común que las engloba y otorga su razón de ser y que se encuentra tan estrechamente vinculado al Canónico que sus fronteras, en ocasiones, se desdibujan como en el Derecho civil y foral (procesal). Un Derecho Canónico que es al mismo tiempo «vis coactiva» y «vis directiva», que cumple una función al servicio de la pastoral, que estructura a la Iglesia y es, también, parte esencial de su sistema inmunológico. Por lo mismo, será pequeña sorpresa el constatar que, en su elaboración y desarrollo, participen de manera por demás activa teólogos, juristas, obispos, oficiales de la Corona, fieles y, entre ellos, los indios. Todos estos actores estaban guiados por la imaginación que surge de la necesidad de resolver problemas ciertos y concretos.

En esta obra nos asomaremos a una historia en la cual el indio, acorde a la evidencia documental, está muy lejos de reflejar la típica imagen de la víctima permanente. Encontramos a los indios de carne y hueso que toman la historia en sus manos para participar de manera activa dentro de la complejidad social a la cual pertenecieron, con el fin de hacer valer el conjunto de privilegios, así como sortear las limitaciones, que implicó el ser definidos jurídicamente como «persona miserable» y cristiano nuevo. Un indio que al mismo tiempo es receptor, beneficiario y actor de una tradición jurídica milenaria.

Tomarse en serio la relación de los indios, el Derecho Canónico y los foros de justicia implica arriesgarse e incursionar en una historia que resulta lejana de aquella imagen maniquea del pasado en la cual se enfrentan los «buenos indios» y los «malos conquistadores»; los astutos naturales siempre en resistencia contra ingenuos o malvados religiosos, obispos y funcionarios obsesionados por su destrucción. Lo que se revela es el complejo mundo de las ideas y las creencias que unían aquella diversidad social y jurídica, afirmándose en esa diversidad dentro de horizontes más o menos definidos y flexibles. Tomarse en serio esta historia es aceptar el reto de enfrentarnos con un pasado cuyos protagonistas son culturalmente católicos, es decir, que se desarrolla en una cultura marcada por los parámetros de la catolicidad, sin importar en principio que tan ortodoxa fuese su observancia. 


\section{El DeRECho y LA MORAL, LAS CREENCIAS y LOS CRÍMENES}

No hay que caminar muy lejos para darnos cuenta que los hombres y las mujeres involucrados en esta historia - laicos indios y no indios, oficiales reales, sacerdotes, obispos o religiosos- forman parte del mismo cuerpo cultural, que participan de las mismas ideas, creencias y prácticas religiosas que se concretan en actos observables. De entre ellos, nos fijamos en los de naturaleza jurídica que tienen estrecha relación con la moralidad de la época, que nos muestran la interconexión del Derecho con la teología — de manera muy especial con la teología moral-, ambas muy vinculadas a la casuística y la tradición. Dos formas de conocimiento que se construyen a partir de la compleja experiencia humana a la cual tratan de encauzar y llenar de sentido, sobre la base de una antropología que sorprende por un realismo que, si bien no se hace ilusiones sobre la virtud cotidiana del ser humano, tampoco deja de esperar lo mejor de cada persona.

En esta lógica, considero necesario observar que la conducta ideal, tipológica podríamos decir, que se esperaba de los indios era la misma que se exigía a cualquier habitante dentro de la Monarquía de España. Sin importar la calidad de la persona o la corporación de pertenencia, los vasallos del rey y fieles de la Iglesia, empezando por el rey mismo, debían ejercitar las virtudes cardinales (prudencia, fortaleza, templanza y justicia), las teologales (fe, esperanza y caridad), cumplir con los mandamientos de la ley de Dios y de la Iglesia, así como llevar una vida dentro de las prácticas litúrgicas, sacramentales y devocionales que nutrieran su religiosidad, con el fin de alcanzar vidas virtuosas en beneficio de cada persona, de su salvación eterna, por el bien de la comunidad y de la Monarquía.

Este modelo de conducta funcionaba como el analogado principal, como un modelo que se abría a un nutrido abanico de posibilidades en las relaciones personales y sociales y no como un código de comportamiento rígido. La virtud debía vivirse en cada caso concreto, realizarse en cada persona acorde a circunstancias específicas. Tal y como lo plasmara Miguel de Cervantes en Persiles y Segismunda, dentro de una vida azotada por los caprichos de la fortuna, sólo la virtud permite al ser humano la flexibilidad suficiente para no traicionar la rectitud de su conducta. Al revisar las vidas de los santos, o las hagiografías tan caras a la época, no encontramos un modelo único de comportamien- 
to sino gran diversidad de posibilidades para alcanzar la virtud, distintos ejemplos de vida que, como las brújulas, señalan un punto cardinal, pero que en manera alguna determinan un solo camino. San Felipe de Jesús, santo Toribio de Mogrovejo y santa Rosa de Lima, como la beata india Salvadora de los Santos que fue una laica dedicada a la predicación de la Palabra y que gozó de la admiración del pueblo, eran modelos de virtud y santidad aunque sus vidas tuvieran, en los hechos, derroteros muy distintos.

El considerar al modelo de conducta como analogado principal, nunca como un código inflexible al estilo puritano, permitirá a la Iglesia presentarse fuerte en sus principios doctrinarios y, al mismo tiempo, moderada, flexible o rigurosa en su aplicación según fuera el caso. Una forma de articular la doctrina y la acción —en este caso jurídica y judicial— que, según he podido observar, es causa de confusión así entre los noveles estudiantes, como entre los expertos. La diversidad de prácticas y manifestaciones religiosas -múltiples y ricas como el arte barroco del cual es proyección-, se confrontan con el analogado principal posibilitando su comprensión caso por caso. Así se podían acercar a zonas de frontera en donde las prácticas empezaban a generar dudas en torno a su virtud o su ortodoxia. Una frontera bastante flexible cuya trasgresión no descalificaba necesariamente a la persona como católica a los ojos de su sociedad e Iglesia, sino que la identificaba como necesitada de ayuda, redención y justicia. Como podemos observar, la relación entre la moral y el Derecho Canónico era dinámica y compleja, tanto como la realidad misma.

Cuando el investigador queda inmerso en los expedientes judiciales de la época y desde ahí reflexiona sobre la juridicidad de las relaciones sociales dentro de los marcos de aquella catolicidad, poco a poco comprende que la conducta trasgresora del Derecho está asociada al pecado, es decir, a una ofensa contra Dios, la Iglesia, el prójimo y la misma persona que lo comete. También que, esta relación afecta por igual las conductas consideradas por el Derecho civil como por el criminal. Obvio es decirlo, en ambos casos el referente a la doctrina canónica, como al Derecho común, era obligado. En esta ocasión nos fijaremos brevemente en las de índole criminal dentro de los foros de justicia en materia religiosa. Su exploración en el terreno civil quedará como asignatura pendiente. 
Conforme el estudioso se adentra en los expedientes va quedando claro que, si bien la conducta a ser considerada en tribunales implicaba en alguna medida un pecado, no todo pecado se convertía en trasgresión del orden jurídico. La criminalidad estaba dada por uno de dos factores o por su combinación: la publicidad con que se actuaba y la gravedad de la falta. Así, acorde a estas consideraciones, es posible dividir los crímenes que se conocían en los foros de justicia en dos grandes grupos: los que no se apartaban del todo del cuerpo de creencias comunes y los que sí lo hacían sin duda alguna.

Los crímenes que no implican apartarse del cuerpo de creencias comunes los podemos dividir, a su vez, en tres apartados dependiendo de la gravedad de los actos. Un primer apartado está referido a los usos y costumbres del común de la cristiandad. Se trata de acciones que en su mayoría hubieran podido solucionarse dentro del sacramento de la confesión, también llamado «foro interno» y que es comprendido asimismo como un tribunal, de hecho el más importante de todos; pero que devienen en crímenes por la publicidad de los actos, por el mal ejemplo, porque inducen a otros a pecar, es decir, por constituir un escándalo. Aquí encontramos el común de los delitos perseguidos por los tribunales eclesiásticos ordinarios y en los tiempos de la visita de los obispos. Como ejemplo, entre muchos otros, podríamos mencionar el amasiato.

Un segundo apartado, todavía dentro de las fronteras de la catolicidad, contiene aquellas acciones que, por su gravedad, no dependían del escándalo para transformarse en crímenes. Se trata de acciones que ofendían alguno de los sacramentos, como la bigamia al matrimonio y la solicitación a la confesión. La infidelidad podía ser materia de corrección en el confesionario mientras no se convirtiera en escándalo, la bigamia era un crimen pues atentaba directamente contra el sacramento del matrimonio. Fallar al voto de la castidad era un asunto de confesionario, mientras que solicitar favores sexuales al momento de la confesión era un crimen perseguido implacablemente.

Un tercer apartado lo forman aquellas conductas que, si bien de alguna manera todavía comparten el común de las creencias, conllevan serios agravantes en su criminalidad. Se trata de acciones que implican un atentado contra el primero de los mandamientos que es amar a Dios por sobre todas las cosas. Por encima de Dios nada puede estar, como tampoco puede ser suplantado por cosa alguna. Es, pues, el más grave 
de los pecados que se transforma en el más terrible de los crímenes cuando se expresa como un pacto con el «enemigo del género humano», con aquel que traicionó de manera definitiva a Dios, es decir, con Luzbel. Cabe advertir que no se trata de creencias paganas pues éstas se abordaban de distinta manera, sino de conductas llevadas a cabo por bautizados sin importar, en principio, la calidad de su persona.

Todos los actores involucrados en estas historias creen en el Demonio, sólo que unos lo rechazan y otros lo desean, unos para temerle y otros para adorarle, unos para evitarle y de ser necesario hacerle frontal guerra y otros para desearle y buscar ser sus aliados. Creer en el Maligno no era una creencia disidente como repetida e inopinadamente se ha dicho. El problema estaba en otro lado, estaba en el ejército en el cual se elegía militar. La meditación de las dos banderas, eje de los Ejercicios espirituales de San Ignacio de Loyola, que tuvieron indudable influencia en aquel entonces, acuden en nuestro auxilio para aclarar el punto. Por un lado están quienes se ubican en el ejército de la Iglesia encabezada por Cristo y, por otro, quienes han hecho una alianza con el «émulo del género humano». Ambos ejércitos traban una lucha tan radical que ningún ser humano puede evadirse y en la cual la indiferencia implica colaboración con Lucifer, ya sea por acción o por omisión. Una batalla en la cual se arriesga el bien más preciado: la salvación eterna.

En este caso, como podemos darnos cuenta, ya no se trata de pecados venidos a escándalo, ni de grandes debilidades humanas, sino de opciones radicales de vida. No obstante, son conductas que participan de las creencias comunes. ¿Quién no creía en Lucifer y en su avérnico ejército? No hay que caminar muy lejos para darnos cuenta de que en realidad no se persigue la creencia, sino la colaboración. Creer en el Demonio es propio del tiempo, pactar con él es necesariamente un crimen con independencia de la publicidad de la conducta.

Como apuntamos líneas arriba, existía un segundo grupo de conductas que se divorciaban y combatían las creencias comunes de la catolicidad como podía ser, por ejemplo, la herejía y la apostasía cual era el caso de judaizantes, luteranos y afines. Se trataba del menos común de los delitos, si bien eran muy espectaculares en su castigo, amén de ser los favoritos de nuestra historiografía puesto que implicaba un castigo directo a la disidencia en las creencias lo que, acorde a nuestros dogmas culturales, constituye una violación a la libertad de pensamiento. 
Entre los herejes y apóstatas sería muy difícil encontrar algún indio pues ellos tenían un nicho aparte en la idolatría y sus derivados, un pecado ciertamente grave pues suponía poner las cosas por encima de Dios y adorarlas, lo que no necesariamente implicaba un pacto con el demonio. Sin embargo, por tratarse de los naturales siempre hubo atenuantes que, por lo regular, derivaban de su condición de cristianos nuevos y miserables. Estos atenuantes los podemos dividir en tres tipos: por causa de ignorancia simple, por engaño de líderes perversos y por engaños del Demonio. En cualquier caso se tenía la justificación de la ignorancia que, si bien no eximía de responsabilidad pues no se trataba de una ignorancia insalvable, sí la reducía considerablemente. No era lo mismo cometer tan grave crimen por perverso que por ser «cristiano nuevo de miserable condición» y por tanto ser merecedor de un trato «benevolente».

No está por demás llamar la atención en el hecho de que el trato «benevolente», esa moderación hacia los indios, nos refiere con claridad a figuras de rancio abolengo dentro del Derecho Canónico identificadas, desde el siglo XI, por Ivo de Chartres sobre la base del estudio de la tradición canónica del primer milenio. Esto es que, frente a conductas trasgresoras del orden jurídico el Derecho puede aplicarse con estricto rigor, de forma moderada o efectuar excepciones, dependiendo de la persona que lleva a cabo la acción y de las circunstancias que le rodean. Esto, por supuesto, no niega la conducta reprobable, mucho menos la existencia del crimen y del pecado, sino que obedece al realismo antropológico que guía la aplicación del orden jurídico canónico, algo digno de ser estudiado en las Indias Occidentales.

En suma, las exigencias de carácter moral que se tuvieron con los indios fueron similares a las demandadas al común de los vasallos y fieles, siempre sustentadas en principios religiosos ordenados al ejercicio de la virtud cristiana. Esto es que, en la transformación del pecado en crimen, es decir, de una conducta reprobable en el ámbito de la conciencia, a otra perseguida y castigada por los foros de justicia, los indios y los no indios «cometían» los mismos delitos en materia religiosa. Sin embargo, por ser cristianos nuevos de miserable condición, los naturales gozaban de trato benevolente por lo que no se les aplicaban los peores castigos. El trato «benevolente» con los indios, es necesario recordarlo, fue un elemento sustancial de un procedimiento judicial técnicamente definido, derivado de un conjunto de predicados 
morales que, como principio doctrinario, impelían al trato preferencial con el débil y a su protección contra el fuerte.

El orden jurídico y judicial sustentado en el Derecho Canónico no estaba sujeto a una racionalidad orientada por la eficacia, es decir, de carácter formal. Diversos factores como el apego al debido proceso, el celo por diferenciar a los indios de los no indios, la traducción jurídica de predicados religiosos de carácter moral, su íntima relación con la acción pastoral, nos señala que la acción judicial estaba orientada sobre todo por una racionalidad sustantiva ordenada a fines éticos, por igual referidos al plano inmanente que al trascendente. A nadie debe sorprender que el Derecho Canónico, como los foros de justicia por éste ordenados, fueran un instrumento al servicio de una pastoral que, en su conjunto, configuró un proyecto cultural en el cual se comprometieron los distintos cuerpos de aquella sociedad e Iglesia y que se sintetizó en la constante «reforma de las costumbres» que, obvio es decir, debemos comprender como un concepto de época. Este orden jurídico y religioso se sustentó en un realismo antropológico que revela un drama histórico en el cual es necesario reflexionar.

\section{EL DRAMA DE UNA HISTORIA}

Con frecuencia olvidamos que, la historia de la relación de los indios con el Derecho Canónico y los foros de justicia se desarrolla dentro de una cultura católica, incluso en sus aparentes y reales disidencias como hemos observado. También, solemos pasar por alto que las religiones implican, necesariamente, una forma particular de comprender al ser humano, su sociedad y su historia de suerte que, sobre esta base, se levantan culturas y civilizaciones.

En esta lógica me parece prudente observar que, es distintivo del cristianismo hacer de la persona el centro de su pensamiento y acción, el motivo de sus esfuerzos y hacerlo en respuesta al radical compromiso de Dios con el ser humano, tan radical que se encarna en Jesús de Nazaret, un simple carpintero de Galilea. El cristianismo es una religión centrada en la persona humana y su íntima relación con un Dios personal. Ahora bien, el cristianismo de tradición apostólica al cual pertenece la Iglesia Católica, no se concibe a sí mismo como la religión de los puros. G. K. Chesterton observaba que la Iglesia Católica es 
semejante a un hospital de pecadores en proceso de rehabilitación. El acceso al hospital, agregamos, no depende de filiación, capacidad o condición alguna, basta con querer ingresar. El drama de una historia vivida en el contexto del cristianismo de tradición apostólica no se desenvuelve a partir de la lucha del bien contra el mal pues no es una religión maniquea, no es el camino de los gnósticos. En esta historia el protagonista es el ser humano y el campo de batalla más importante es el corazón de cada persona, su conciencia, que se debate entre la gracia y el pecado.

Cuando se habla del mal se refiere al pecado y sus consecuencias. Cuando se trata del bien se refiere a la gracia de Dios quien la ofrece de manera gratuita y generosa. El pecado, entonces, es el rechazo que hace el ser humano de la gracia, lo que tiene consecuencias malas para la persona, la sociedad y su historia. La gracia sin excepción es ofrecida en gratuidad por Dios; pero debe ser aceptada por el ser humano ahí donde la libertad tiene su morada que es su conciencia. Cada persona es por necesidad libre y no puede menos que elegir en cada momento, de manera constante, en un proceso que involucra sus deseos, sus anhelos, sus potencias y limitaciones, sus lazos de solidaridad con los demás, su relación con Dios. Se trata de una libertad estrechamente vinculada a la conciencia, la responsabilidad y el bien. Por lo mismo, renunciar a la libertad es tanto como renunciar a la propia humanidad y vencerse ante el pecado. Lo cierto es que tal renuncia nunca se realiza de manera definitiva pues la gracia no desaparece, ni deja de actuar de mil maneras para atraer la voluntad de cada persona, sin forzarla. Esta dinámica de vida transforma la historia — sea personal o social— en historia de salvación. Cualquier historia, por insignificante que pueda parecer, está vinculada a la gran historia. Cada persona importa.

Esta forma de comprender la historia está sustentada en un profundo realismo antropológico. Una de las metáforas preferidas en aquel entonces para explicar la condición del ser humano era considerarle como un «ángel caído». Un ser creado a imagen y semejanza de Dios con vocación trascendente que por su decisión, por su pecado, lastimó su relación con Dios al pretender ser como su creador. Tal es el llamado pecado original que señala su condición de debilidad y su necesidad de la gracia de Dios para fortalecerse y seguir adelante. Una apertura a la gracia que sólo en libertad se puede verificar y que sólo libremente se puede recibir. 
El ser humano es limitado y es trascendente. Sus limitaciones no le impiden lanzarse a las más grandes aventuras en las cuales encontraremos actos de profunda humanidad y de terrible mezquindad en el mismo tiempo y espacio y, en no pocas ocasiones, en la misma persona para confusión de no pocos historiadores. El ser humano es al mismo tiempo egoísta y generoso, vanidoso y humilde, capaz de la más excelsa virtud y sacrificio, como de la más abyecta traición. Cima y sima de la creación. El literato inglés J. R. R. Tolkien lo expresó de manera por demás poética en El Señor de los Anillos. El Hombre es generoso y voluble, dispuesto a ofrendar su vida para derrotar a Sauron, capaz de lanzar una grandiosa cargada de caballería con rumbo a las lanzas de los orcos; como de tener el anillo en sus manos, la oportunidad de destruir a Sauron y traicionar en el altar de la soberbia por ilusiones de grandeza. Un ser que, al tiempo de generar desconfianza en sus aliados, es reconocido como el único con suficiente dignidad como para empuñar la espada y ceñirse la corona del rey. En el combate contra Sauron todos, sin distinción, son tentados por el poder del anillo, por la soberbia. Los más son heridos en batalla y deben ingresar al hospital de los pecadores, expiar culpas, asumir responsabilidades y ser curados por la gracia para salir cuanto antes a continuar en el combate. No hay zonas de seguridad y confort. El pecado no espanta pues forma parte del drama de cada día, lo que asusta es sucumbir ante éste, no poder levantarse para seguir en la batalla por alcanzar la eternidad que, en no pocas ocasiones, se confundirá con la gloria terrena.

Dios, en esta historia y con perdón de san Anselmo, está muy lejos de ser impasible. Por el contrario, está apasionado por el ser humano en forma tal que, literalmente, ha comprometido su propia sangre en Jesús de Nazaret. Como es de suponer, en esta historia el Demonio también tiene su papel que, definitivamente, no es el de una divinidad en guerra contra el Dios del bien. El Demonio es la criatura caída y sin redención que aprovecha las fisuras que la soberbia abre en la voluntad humana para intentar confundir su libertad y cautivar su voluntad. Es el amo del engaño, una criatura vanidosa, astuta, motivada por la envidia al ser humano, por el rencor a Dios. Sin embargo, no es más que una simple criatura incapaz de aceptar la redención, aquel que cayó de manera definitiva por su propia decisión.

El ser humano es libre y es responsable de sus actos. Es tan libre que puede volver la espalda a su creador, renegar, patear y ponerse en su 
contra. Incluso puede intentar sustituirle por algo que le sea factible manipular del mismo modo en que el brujo y el mago lo pretenden. En el extremo, es capaz de sustituir a Dios por sí mismo cual Narciso que, al contemplarse en el espejo, se cree capaz de controlar cuanto le rodea aunque no lo sea ni de manejar la imagen que contempla. Es entonces que se comete el pecado de la idolatría. Un pecado que subvierte el orden de la creación al pretender que la criatura sea Dios con graves consecuencias también en el orden social. No obstante, es el pecado más fácil de perdonar por Dios a condición de que el ser humano cambie, se convierta, es decir, acepte el orden natural de las cosas y su condición de criatura abierta a la gracia, a la redención de Dios.

Cuando los historiadores nos adentramos en el drama de una historia sustentada por este realismo antropológico resulta difícil encontrar medias tintas. La apatía y la mediocridad existen como en cualquier lugar, pero son percibidas como tentaciones, como actitudes contrarias a la redención y por lo mismo deben ser combatidas. Así, de cara al tema que aquí nos ocupa, podremos observar la capacidad de una Iglesia local, por grande o pequeña que sea, para movilizar ingentes recursos con el fin de erradicar la idolatría de un puñado de indios en un paraje en medio de la nada - o cualquier costumbre que induzca al pecado- para, al final, aplicar las correspondientes penas, en pocas ocasiones con rigor y en las más con moderación o disimulo en mor de la condición humana. De igual suerte, los expedientes nos desvelan historias de seres humanos de carne y hueso, indios y no indios tan mortales como cualquier otro, con sus anhelos y esperanzas, con sus problemas cotidianos y extraordinarios, tan dispuestos a colaborar en la reforma de las costumbres, como de sacarle la vuelta, de sumarse al esfuerzo, como de sabotearlo. En su propia lógica, de aceptar la gracia a través de diferentes medios pastorales, como de voltearle la espalda. Al final de día, hombres y mujeres plenos de humanidad. Cabe preguntarnos ¿por qué ese afán de comprometer tantos recursos humanos en una empresa que, de antemano, se sabe que sus resultados serán limitados en el mejor de los casos? Porque tienen por sabido que en la historia, para aquellos que permanecen en la lucha, el alcanzar la cumbre es cosa cierta, contra lo que Sísifo y sus intérpretes pudieran opinar. Estamos ante una racionalidad distinta a la que domina en nuestra época, tan denodadamente volcada a la eficacia, tan marcada por el eficientismo y el principio de utilidad. Como sea, el historiador 
debe hacer el esfuerzo de comprender la racionalidad de aquellos de quienes escribe la historia.

Ahora puede quedar más claro que, la estrategia del combate al pecado consiste en poner al ser humano en condición de aceptar la gracia que le justifica y fortalece, que le permite ponerse en pie y tomar las decisiones correctas en orden al bien personal, social y trascendente, en el entendido de que no se logrará de una vez y para siempre. Una estrategia que pone en movimiento una compleja acción pastoral comprometiendo sacramentos, liturgia, educación de las masas y de las elites, predicación de la Palabra, la formación de organizaciones sociales, como también el uso de medios jurídicos y judiciales. Ahora podremos ver con más claridad que el Derecho Canónico, con sus tribunales, no es un fin en sí mismo, sino que está al servicio de la acción concertada de la Iglesia para alcanzar la salvación de cada persona y de todas las personas. El Derecho Canónico no es el príncipe de la historia, tampoco un caballero enfundado en su deslumbrante armadura. Es tan sólo un fiel sirviente, indispensable, culto, técnicamente muy sofisticado, imprescindible, que puede ocupar lugares de gran realce, tan necesario que cuando falla compromete el buen camino de la acción de la Iglesia; pero a final de cuentas no es más que un fiel sirviente.

Sólo en medio de este drama se puede entender la política de contención y encauzamiento tan propia del cuidado de la ortodoxia y la reforma de las costumbres que maraca aquellos años. Por eso el recurso judicial, con excepción de la confesión sacramental, se comprende como complementario y vinculado a la acción pastoral. Esto es muy claro, por ejemplo, durante una visita episcopal - general o especial, da lo mismo- en donde se hace presente el aparato religioso en pleno y, como parte de éste, la acción jurídica y judicial. En cualquier acción pastoral un conjunto de recursos humanos y materiales se ponen en marcha para salvar a cada persona y a todas las personas, insistimos, con la clara conciencia de que se volverá a caer, se volverá a fallar puesto que su condición es la de ángeles caídos con vocación trascendente. No son los resultados lo que orientan la acción, sino la pasión por la salvación de cada persona, un asunto en lo que honestamente creen y en lo cual comprometen, como decían entonces, fama y fortuna. Fuera de esta lógica, extraviamos el sentido de las acciones de aquellos seres humanos. A partir de aquí las posibilidades de investigación e 
interpretación se multiplican. Es un punto de partida para el investigador, no la meta a conseguir.

Si observamos con detenimiento y reflexionamos con serenidad, será sencillo darnos cuenta de que estos dramas son análogos a los desarrollados con genio y profundidad por Lope de Vega, Miguel de Cervantes, Pedro Calderón de la Barca, santa Teresa de Ávila, san Juan de la Cruz, sor Juana Inés de la Cruz y William Shakespeare; como, en tiempos más recientes, Fiodor Dostoievsky, León Tolstoi, Graham Green, Michael O’Brian, Javier Sicilia, C. S. Lewis, J. R. R. Tolkien y K. G. Chesterton, por citar algunos literatos de antaño y hogaño, que se han hecho cargo de la complejidad del drama humano, acorde a la comprensión que de la historia y la persona tiene el cristianismo de tradición apostólica.

Antes de terminar estas apretadas reflexiones, me parece pertinente salir al paso de ciertos prejuicios que entorpecen la comprensión de una historia que se desarrolla en un contexto cultural de tradición apostólica, concretamente del catolicismo romano. Es, pues, importante seguir el consejo de estudiosos de indudable solvencia como Emilio Durkheim, Max Weber y Luis González y González quienes invitan a identificar aquellas fobias que no nos dejan observar con calma el objeto de estudio. En esta ocasión me quiero referir al «complejo romano» - $\tan$ bien descrito por Hans Urs von Balthasar- y al «complejo puritano».

$\mathrm{El}$ «complejo romano» indica que nada bueno, cierto, justo o noble puede provenir de la Roma católica en el presente y mucho menos del pasado. Si es católico debe ser falso, incompleto o perverso. Es necesario insistir, una vez más, en que los historiadores no estamos para elaborar juicios flamígeros de los ancestros, mucho menos para generar opinión política usando el discurso historiográfico, que esa opinión tiene su lugar y su propia forma discursiva. Los historiadores estamos para comprender procesos históricos dentro de un tiempo y lugar específicos, cuyos protagonistas son siempre seres humanos de carne y hueso y no simples cosas que puedan usarse según las necesidades discursivas o las conveniencias políticas de moda. Como cualquier persona, como todos los muertos, los pasados merecen respeto y consideración.

Por otro lado, el prejuicio puritano indica que en la historia sólo existe un discurso posible el cual siempre coincide con el propio. Este prejuicio lo podemos encontrar en diversas presentaciones, ya se trate 
de la historia de una nación, de una religión, de una raza, clase o género, grupo social poderoso o «marginado», etc. Se trata de historias puritanas en donde no existe más discurso que el del propio historiador - y de su grupo de intereses-, a través del cual se justifica la historia. Se trata de construcciones historiográficas univocistas que, por ende, resultan ser esencialistas, teleológicas y anacrónicas como es propio de las posturas puritanas. Podemos odiar o amar a la Iglesia Católica, renegar o apreciar el pasado «colonial», pensar que el Derecho en un instrumento del poder o un mecanismo de justicia sin igual. Sin importar filias o fobias, al estudiar una historia que se desarrolla en una cultura católica la lógica del drama humano arriba descrito estará presente y el reto será comprenderlo, no juzgarlo.

Nadie debe llamarse a sorpresa cuando, a lo largo de este libro, descubra que los indios fueron protagonistas de su propia historia y que vivieran con intensidad su propio drama en las coordenadas de su propia cultura, que creyeron y dudaron, que pelearon en tribunales, que se arrepintieron de sus pecados y volvieron a pecar como cualquiera en su tiempo, que vivieron con pasión y decisión. La intensidad del peregrino de los Andes, al cual este libro dedica un capítulo, no es diferente a la de los personajes de Lope de Vega, de Cervantes o Shakespeare; su profundidad espiritual pertenece al linaje de sor Juana Inés de la Cruz, de santa Teresa de Ávila, de san Juan de la Cruz, de san Ignacio de Loyola; su pasión por el indio es del mismo talante que la de fray Toribio de Benavente «Motolinía» y Bernardino de Sahagún. Y, no obstante, Guamán Poma de Ayala es un hombre de su tiempo como diría Perogrullo, es el portador de un mensaje y no el creador único de aquella realidad. Esta es la historia que se encuentra en la relación que establecieron los indios con el Derecho Canónico y los foros de justicia en materia religiosa. En suma, observamos la intensidad con que fueron vividas esas dos metáforas que explican una historia que se despliega en el contexto del cristianismo de tradición apostólica en su vertiente católica romana: el Derecho y la religión.

Jorge E. Traslosheros Junio de 2010 
02-introduccion.qxd 11/09/2010 4:31 PÆgina 26
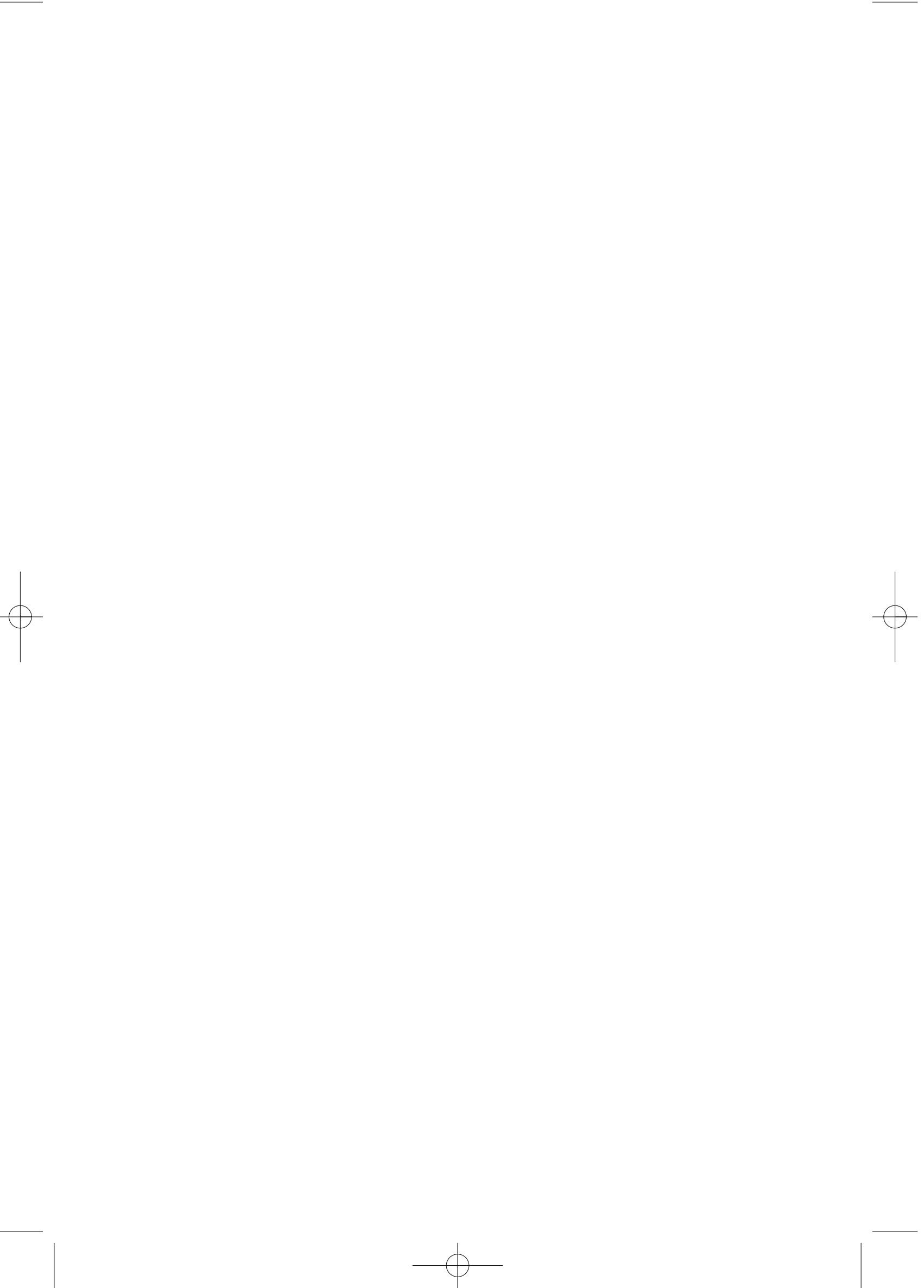


\title{
Reflexiones en torno a la recepción del derecho eclesiástico por los indígenas de la Nueva España
}

\author{
Ana de Zaballa Beascoechea
}

\section{INTRODUCCIÓN}

Ha sido común al estudiar la transformación de la cultura indígena en la época colonial, atribuirla a dos factores: a la política de la Corona que buscó explícitamente la castellanización, y a la acción de los misioneros, que en ocasiones secundaron esa política, y según algunos estudiosos en su tarea evangelizadora y educativa transformaron estas culturas e impusieron formas de vida occidentales ${ }^{1}$. En este sentido se ha discutido sobre la intencionalidad del clero; si primaba el afán evangelizador o la castellanización; el servicio a los intereses de la Corona o al bien de los nuevos cristianos; si defendían con sus traducciones el mantenimiento de las culturas indígenas o sí las desvirtuaban con su mentalidad europea.

Falta a mi entender una tercera explicación: la voluntad de parte de la población indígena de apropiarse de la cultura, el derecho y privilegios que ofrecía el nuevo orden establecido.

En este trabajo, presento una muestra de la recepción de la práctica judicial por parte de la población indígena; se puede considerar, también, como recepción de la cultura judicial castellana —-después indiana-, que ponen al servicio de sus intereses. Examinaremos con este fin fuentes derivadas de la actividad judicial eclesiástica. Teniendo en cuenta que el presente artículo es el preámbulo de una investigación

1. Duviols, 1986, 2003; Klor de Alva, 1991; Tavarez, 2002. 
mayor, en curso, y partiendo de una selección de casos, exploro algunas actuaciones judiciales que nos permiten comprobar la soltura con la que actúan los indígenas en los foros de justicia.

La documentación que se analiza es fundamentalmente la ofrecida por los archivos episcopales y especialmente la derivada de los tribunales diocesanos. En algún caso haré uso de pleitos seguidos ante la justicia secular pero siempre tendrán relación a la justicia eclesiástica. Como es sabido, en Indias dentro del complejo orden judicial ${ }^{2}$, aunque en un primer momento se aplica el derecho castellano, muy pronto surge el derecho indiano -el derecho producido en Indias o para las Indias-, pues el derecho castellano, enormemente casuístico, no ofrecía soluciones a las novedosas situaciones encontradas en el Nuevo Mundo ${ }^{3}$. Del mismo modo, en el ámbito eclesiástico regirá en principio el derecho canónico general y surge, con el andar de los acontecimientos, el derecho canónico indiano. En esta línea y dentro del tema tratado en estas páginas se podría rastrear la formación del derecho indiano, cómo se reciben las prácticas judiciales en Indias - también las eclesiásticas - hasta formar el derecho indiano... en su especificidad indígena. Utilizaré, fundamentalmente documentación del siglo XVIII y sólo puntualmente alguna referencia al siglo XVI y XVII; esta referencia sirve para comprobar que, a pesar de los cambios que se producen en estos siglos, los indígenas estarán igualmente presentes en los foros de justicia.

Los tribunales episcopales tuvieron una jurisdicción amplísima pues les incumbían asuntos sobre moralidad, costumbres y sacramentos. Esto suponía detentar autoridad sobre todo lo relativo al matrimonio, al cumplimiento con la Iglesia, la resolución de testamentarias, mandas pías, fundación de capellanías, funcionamiento de las cofradías y de sus bienes, etcétera. Para la población indígena, la Audiencia eclesiástica entendía también de los casos de herejía pues, como es sabido, desde el momento de la implantación del tribunal de la Inquisición en Indias, el Santo Oficio perdió su jurisdicción sobre este sector de la población y esa potestad volvió a los Obispos.

La documentación que estamos trabajando nos ha llevado a un cambio de óptica. En los estudios referidos a las relaciones entre igle-

2. Traslosheros, 2006.

3. Cfr. Dougnac Rodríguez, $1998^{2}$. 
sia y población indígena, el indio es visto siempre, o casi siempre, como sujeto pasivo y, por ende, reprimido ${ }^{4}$; en la actividad judicial, en cambio, el indio aparece en muchos casos como sujeto activo, como quien lleva la iniciativa de la actuación. Espero poder mostrar que los indígenas se apropiaron de la legalidad, tanto del derecho castellano como el indiano, así como el canónico de las Indias. En un relativamente corto espacio de tiempo, el derecho - $\mathrm{y}$ «sus» derechos bajo el nuevo orden instituido-, las instancias judiciales y muchos valores dentro de ese régimen judicial, fueron asumidos pacíficamente —con normalidad- por la población indígena ${ }^{5}$.

El estudio tiene tres objetivos ${ }^{6}$ :

1. Calibrar el conocimiento que la población indígena tenía de la legislación castellana.

2. Revisar si existió lo que podríamos llamar un «mestizaje legal», es decir, si los indios utilizaron la legislación castellana —o indianapara defender su cultura y tradiciones, sus sistemas de sucesión.

3. Y, finalmente, si de esos pleitos se puede deducir que habían hecho suyas costumbres castellanas o criollas; en definitiva que habían asimilado en algunos aspectos la cultura y mentalidad criolla.

CONOCIMIENTO DE LA LEGISLACIÓN POR PARTE DE LA POBLACIÓN INDÍGENA

Querría comenzar con algo quizá obvio. Aunque encontramos a individuos que no pertenecen a la nobleza o a los llamados principales, por lo general los temas relacionados con los derechos de sucesión, alianzas matrimoniales, etcétera, van a estar protagonizados por los antiguos señores y caciques... o por aquellos indígenas que tras la conquista prosperaron y se asimilaron a éstos por medio de su situación

4. Aramoni Calderón, 1993, pp. 367-387; Gareis, 1999; Griffiths, 1996, etcétera.

5. Es evidente que en las fuentes judiciales nunca está representada la totalidad de la población; pero aun con esta salvedad, es evidente que una parte significativa de los naturales acudió a los tribunales eclesiásticos. Además, en la Audiencia eclesiástica hay asuntos que exceden lo delictivo, lo reservado a personajes de relieve, en concreto, los asuntos matrimoniales. Vid. Sobre el funcionamiento y actuación de la Audiencia Arzobispal de México: Traslosheros, 2004.

6. Lo que se ofrece será revisado cuando se culmine el estudio en profundidad. 
económica o sus méritos ${ }^{7}$. Lógicamente estos grupos serán los primeros interesados en conservar su poder y liderazgo, y conservar su prestigio en el nuevo orden establecido. Uno de los medios para mantener sus cotas de poder fue el conocimiento y uso de la justicia, tanto secular como eclesiástica.

Entre los historiadores del derecho hace ya tiempo que se habló del indio "pleiteador y litigioso» presente desde comienzos de la época colonial. Andrés Lira ${ }^{8}$ asegura que los naturales enseguida aprendieron los medios y la fuerza de la jurisdicción y podríamos decir que fueron «aprendices precoces» del derecho castellano e indiano y de las posibilidades que éste les brindaba en beneficio propio. Asegura que hay muchos ejemplos en lo referente a la justicia real y pocos a la eclesiástica. Podemos afirmar, casi quince años después, que también en los tribunales eclesiásticos se encuentran muchos ejemplos de indios como iniciadores de pleitos, apelaciones o recursos de fuerza.

Esta documentación es testigo de que los naturales hicieron un uso concienzudo del derecho y a veces abusivo, cuando utilizaron la legislación para obtener beneficios no confesados; de que conocían las posibilidades que les ofrecían las diferencias entre la justicia secular y la eclesiástica. Me detendré en algunos ejemplos más significativos. Comencemos con un ejemplo del siglo XVII.

Los cronistas de idolatrías, como Pedro de Feria ${ }^{9}$ para Chiapas o Gonzalo de Balsalobre para Oaxaca, recogen ejemplos de esta actividad judicial en los siglos XVI y XVII.

En Oaxaca, en 1654 tras las averiguaciones que realiza Gonzalo de Balsalobre, cura beneficiado del Partido de Zola, descubre entre su feligresía abundantes prácticas idolátricas, sobre todo entre los principales, y lo eleva al Tribunal Episcopal. El obispo falla sentencia contra los indígenas principales implicados en idolatrías; la pena impuesta no es dura pero sí humillante, y sobre todo merma el prestigio que esta élite indígena tenía sobre la población. Por este motivo, el Gobernador, Alcaldes, principales y demás oficiales de la República del pueblo y cabecera de Zola, jurisdicción de Zimatlan,

7. Cruz, Gil, y Rojas, 2007; Hillerkuss, 2001a, 2001b.

8. Lira, 1995, p. 771; Duve, 2004 y los autores por él citados.

9. Pedro de Feria, «Revelación sobre la reincidencia en sus idolatrías de los indios de Chiapa después de treinta años de cristianos», pp. 381-392. 
estando en este estado las caussas, ganaron Provisión Real (los Naturales del dicho Partido de Zola) para que se llebase lo actuado (por el Reverendo Obispo de dicha ciudad y el licenciado Gonzalo de Balzalobre) a la Real Audiencia, por vía de fuerza.

No se trata de una denuncia cualquiera, sino de la utilización del recurso de fuerza ante una sentencia del Tribunal Eclesiástico que les era desfavorable. Llama la atención tanto por lo atrevido del recurso, como por su confianza en las posibilidades de la justicia secular frente a la eclesiástica.

La respuesta del fiscal, les fue desfavorable ${ }^{10}$, pero lo intentaron. Quienes recurren los autos son los «principales» - lo que englobamos como nobleza indígena-, que sabían que poco había que hacer en un caso de idolatría ante la justicia eclesiástica, y conocían las posibilidades de trasladar el caso a la jurisdicción secular. Deciden, por tanto, enfrentar los límites y potestad de ambas jurisdicciones, y se acogen a la vía de fuerza contra el obispo. Como se ve, su conocimiento legal —o su asesoramiento, lo mismo da- atendía a aspectos sutiles. La relación entre justicia secular y eclesiástica la manejan según su interés.

Un siglo y medio más tarde los indígenas siguen actuando frente a la Audiencia eclesiástica; veamos varios ejemplos. En 1791 el indio Raymundo Manuel de los Santos, tributario y natural de Cotzocon, obispado de Oaxaca, había sido acusado por idolatría. Fue preso en la cárcel eclesiástica y mientras se terminaba el proceso le embargaron sus bienes.

El indio Raymundo - parece que con el apoyo del cabildo indígena-, apeló en primer lugar la sentencia del Tribunal Episcopal de Oaxaca ante el Arzobispado de México, y mientras se tramitaba ésta, apela también al Juzgado de indios de la Real Audiencia quejándose

10. «En las causas fulminadas contra los Indios, de que consta en los treinta cuadernos, traídos por vía de fuerza a esta Real Audiencia, sobre idolatrías, sortilegios y otras abominaciones y herrores contra la Fee, y Religión Christiana, se deve declarar que no haze fuerza el Reverendo obispo de Oaxaca a quien se debe devolver, y remitir, para que como le toca (...) proceda al castigo de los culpados» (Gonzalo de Balsalobre, «Relación de las idolatrías, supersticiones y abusos en general de los naturales del Obispado de Oaxaca», p. 368. El texto de Balsalobre actualmente también puede consultarse en Cervantes virtual: www.cervantesvirtual.com/servlet/SirveObras/24694941101136941754491/p0000001.htm). 
del embargo de sus bienes, puesto que estaba prohibida la incautación a los indios aunque fuera para costa y otras penas ${ }^{11}$.

Logra el malestar del provisor del Arzobispado ante los requerimientos del virrey; y aunque no sabemos en qué quedó la sentencia por idolatría, logró la devolución de sus bienes.

Encontramos pruebas del conocimiento judicial de los naturales en las innumerables quejas contra curas - unas ciertas y otras no-, en las que si no obtenían ayuda del obispo acudían ante el Juzgado de Naturales de la capital como «pobres miserables». En 1753 el alcalde y naturales del pueblo San Pedro Quiatoni, sujeto al de Teutitlan del Valle de Oaxaca, acudieron a la Audiencia de México, para obtener justicia frente a los excesos de su cura quien les cobraba obvenciones más elevadas de lo aprobado y les exigía además trabajos personales sin pagarles salario ${ }^{12}$.

Como el cura desoyó varias veces las provisiones para acabar con las exacciones indebidas, los indios acudieron a diferentes instancias para obtener justicia. Se dirigieron al obispo, al alcalde mayor ${ }^{13}$ y por último a la Audiencia de México.

Los naturales demostraron su tenacidad y su conocimiento legal. Acudieron una vez más al Juzgado de Naturales de la Real Audiencia y exigieron justicia en todos los puntos: las obvenciones, los trabajos impagados por parte del cura y la devolución de los 300 pesos cobrados injustamente por parte del teniente de alcalde; a esto añadieron su queja por el elevado coste que les suponía acudir a México. Además, como medio para evitar que de nuevo se desoyeran las directrices de la Audiencia, obtuvieron Real Provisión de ruego y encargo para el Cabildo en Sede Vacante y para el alcalde mayor, de forma que ambas jurisdicciones velaran por su cumplimiento.

En el ámbito local destacan casos como el protagonizado por dos indios del común del pueblo de Ayoquesco, Oaxaca, en $1752^{14}$. Hipólito de los Santos y Pascual de la Virgen que acuden al tribunal del

11. AGN. Bienes nacionales. Volumen 149, exp. 25, 1791.

12. AGN, Indiferente virreinal, Caja 1531, exp. 8, 1753.

13. Que también les cobró en exceso - 300 pesos- con la excusa de que su teniente estaba fuera y debían pagar las costas. AGN, Indiferente virreinal, Caja 1531, exp. 8, fol. $43 \mathrm{v}^{\circ}-44 \mathrm{r}^{\circ}$.

14. Archivo del Estado de Oaxaca (desde ahora AEOx), Sección curia de justicia, Serie Asuntos criminales, Leg. 1, Exp. 23: Hipólito de los Santos y Pascual de la Vega 
obispado para denunciar al alcalde indígena y al cura de la doctrina por no respetar la inmunidad eclesiástica.

El atropello comienza cuando los dos denunciantes huyen del alcalde que les estaba golpeando en la plaza por algún delito y se refugian en sagrado. Según su denuncia, el cura llama al alcalde, y convencido por este de que había peligro de motín, les manda azotar y les mete en la cárcel pública hasta el día siguiente.

Es significativo que dentro de una situación no del todo clara, estos dos indígenas presentaran apelación ante el obispo no por razón del castigo o por su exceso, sino por el atropello a la inmunidad eclesiástica del dicho alcalde y también del cura que tampoco la respetó, así como por su comportamiento, pues andaba por el pueblo como conchabado con el alcalde indígena.

En su defensa, afirman, claramente exagerando, que todo el pueblo está escandalizado, de

que la casa de Dios no protexa al que se refugia en ella; y no causa tanta admiración de lo ejecutado por dicho alcalde (...) y si lo ejecutado por el padre cura fray Francisco Gonzalo que en lugar de favorecernos cooperó al castigo y nos metió en la cárcel.

El Tribunal Eclesiástico aceptó la queja y aunque amonestó por su conducta a los denunciantes, también advirtió al cura sobre la necesidad de defender la inmunidad eclesiástica. No podemos olvidar que en la segunda mitad del siglo XVIII, la inmunidad junto al fuero eclesiástico eran elementos paradigmáticos en la defensa de la autonomía de la potestad eclesiástica. Podemos decir, que en gran medida, el Vicario general del obispado, les da la razón.

Habría otros ejemplos, como la apelación que presentan los miembros del Cabildo de Yagayo al obispo para remover al fiscal de igle$\operatorname{sia}^{15}$. La queja contra Miguel de los Ángeles, alguacil fiscal, se basa en su mala conducta, sus vicios de embriaguez, ser jugador de naipes y

contra Pascual Pérez, alcalde que fue de ese lugar por arbitrariedad a la inmunidad eclesiástica, 1752

15. AEOx: Sección curia de justicia, Serie Asuntos criminales, Leg. 1, Exp. 20, y 21: El pueblo de Yagago contra Miguel de los Angeles Alguacil mayor, fiscal de doctrina sobre los capítulos que se expresan, 1751. 
ladrón; faltas consideradas leves, y sobre las que el propio cabildo tenía jurisdicción ${ }^{16}$. Por tanto, no era necesaria la intervención del obispo para castigarle por sus vicios — de hecho ya lo había sido-, sino para despojarle del cargo de fiscal.

Como es sabido, el fiscal de iglesia, miembro del cabildo, es nombrado por el cura y los miembros del cabildo indígena ${ }^{17}$. En el caso que nos ocupa hubo alguna irregularidad en su nombramiento ${ }^{18}$, y para removerle necesitaban la aprobación del cura de la parroquia — cura interino, en ese momento— ${ }^{19}$, quien se negó, por lo que decidieron apelar al Obispo.

Después de muchas averiguaciones y el interrogatorio de testigos, el fiscal es destituido y se indica por decreto del vicario general de la diócesis que «la república y electores de dicho pueblo de Yagayo nombren otro fiscal de la capilla y coro de aquella iglesia parroquial».

16. Así lo demuestra la queja de los principales y del Cabildo del pueblo de Tulansingo en 1656. Recurren ante el Juzgado de indios de México porque el alcalde mayor les obliga a llevar a la cabecera desde su pueblo, a los naturales que prendiesen por causas leves. Protestan y se quejan porque tienen jurisdicción para conocer las causas leves, y concretan qué consideran causas leves: «como son borracheras, amansevamientos y cobransas de tributos, segun su titulo y nombramiento despachado por govierno, y que tienen su carsel para ello» (AGN, Indios, Volumen 20, exp. 125, 1656).

17. Sobre el papel de los fiscales indios y los conflictos con la justicia secular y eclesiástica, vid. Gómez García (en prensa). En concreto esta investigadora confirma que los fiscales formaban parte del cabildo indio pero su función se encontraba en la iglesia, es decir, estaban situados dentro de la iglesia aunque se colegiaban también con el cabildo. Su vinculación jurídica estaba en las dos esferas. Esta es la razón por la cual los sacan de cabildo a veces o se pelean con los gobernadores: precisamente por las atribuciones políticas y legales que tenían (eran notarios por ejemplo, sin necesidad de estar conformados en cabildo, como era menester hacerlo en el caso del poder secular de la República de Indios). Lidia Gómez ha estudiado la institución novohispana y considera que era una institución con mucha independencia respecto al cura pero siempre actuaba bajo la sombrilla jurídica del derecho canónico y también del secular. Lamentablemente no se ha estudiado la fiscalía como institución en sí misma, sino siempre en función del cabildo o bien de adoctrinador de la iglesia

18. El cura lo nombró sin el voto del cabildo indígena.

19. En el escrito al obispo, los cargos de república comienzan su requerimiento ladinamente «el pueblo y común de Santiago Yagayo parescemos diciendo que aquél triste rebaño se halla muy desconsolado y en peligro de ruina espiritual que ocasiona Miguel de los Ángeles, fiscal que puso nuestro cura difunto sin voto, su elección de nuestro común, que conoce y sabe los vicios que concurren en dicho Miguel de los Ángeles» (AEOx: Sección curia de justicia, Serie Asuntos criminales, Leg. 1, Exp. 20, y 21: El pueblo de Yagago contra Miguel de los Angeles Alguacil mayor, fiscal de doctrina sobre los capítulos que se expresan, 1751). 
Se podrían citar pleitos por reclamación de tierras, nombramientos, uso de bienes de la iglesia, falta de atención religiosa ${ }^{20}$, etcétera, en los que se verifica su conocimiento y agudo uso de la legislación eclesiástica.

\section{AsUntos MATRIMONIALES INDÍGENAS EN EL TRIBUNAL ECLESIÁSTICO}

Para comprobar la asimilación de las costumbres y derechos castellanos por parte de la población indígena, me he dirigido a los conflictos relativos al matrimonio porque entran de lleno en la vida social y familiar, en los motivos de poder y prestigio presentes en todas las culturas.

Se podría argumentar contra esta supuesta apropiación, que las costumbres matrimoniales fueron impuestas desde el momento en que se vigiló y castigó la poligamia. Si bien esto es cierto, hubo otros aspectos en torno al matrimonio que podían no haber sido asumidos. Los indios presentaron sus querellas, quejas y demandas por asuntos que consideraríamos propios de la sociedad criolla. Nos referimos a la importancia dada a la promesa de matrimonio, la libertad de la mujer para casarse $\mathrm{e}^{21}$, o la exigencia del permiso paterno para el matrimonio de hijos menores de edad, sobre todo cuando se trataba de matrimonios desiguales. Todo esto habla de una asimilación de gran calado de pautas matrimoniales y sociales.

En los asuntos matrimoniales ${ }^{22}$ la población indígena, hace uso de la normativa canónica, de costumbres antiguas en Castilla o de cédulas reales, para defender sus derechos. No son infrecuentes expedien-

20. AGN Indiferente Virreinal, Caja 1531, Indios, 8, 6 Fojas. San Pedro Luintoni, obispado de Oaxaca. Los naturales del pueblo de San Pedro Luintoni, sujeto a el de Tlacolula del Valle, en el obispado de Oaxaca, contra su cura sentenciado el Bachiller Don Manuel de Vetancur, por derechos parroquiales, 1753.

21. En ámbito mexicano, el I Concilio Provincial de 1555 denuncia la costumbre «entre los indios macehuales de no casarse sin licencia de los principales, ni tomar mujer sino dado por su mano", con la consecuencia de que "el matrimonio no tiene entre las personas libres la libertad que debe tener» (Concilio I Mexicano, cap. 72, en Concilios provinciales primero y segundo, 1769). Vid. Margadant, 1980; Kellogg, 2005; Latasa, 2005; Latasa Vasallo, 2008.

22. La información que cito es preferentemente del siglo XVIII. Vid. AEOx, Fondo Obispado de Oaxaca, Curia de gobierno y administrativa, Serie matrimonios, bautizos y defunciones, exp. 15, Diligencias seguidas para negar el permiso de realizar matrimo- 
tes y diligencias sobre asuntos matrimoniales en los que indios del común acuden a la promesa de matrimonio para exigir que la otra parte se case con el /ella y no con quien pretende hacerlo. En alguna ocasión dicha promesa es falsa o lo son las circunstancias que según el denunciante, reforzaban dicha promesa (como la unión de cuerpos) ${ }^{23}$.

También es habitual exigir la libertad para la validez del matrimonio ante las presiones de la otra parte, del cura, o de los padres. El caso, por ejemplo, de Paula María, india, que solicita justicia al señor provisor pues el cura de su pueblo, San Lucas Teitipaque, Manuel Joseph Calvo la obliga a casarse con Pedro González que es el inductor de la actitud del padre cura. Ella suplica, además, que el obispo envíe superior orden al cura de su pueblo «para que me asista al matrimonio que tengo tratado y pretendo contraer con Jacinto García, natural de dicho mi pueblo» ${ }^{24}$.

Asimismo se defiende la libertad de la mujer en dos pleitos por incumplimiento de palabra de matrimonio, en los que se discute al mismo tiempo esta libertad y el consentimiento paterno. En ambos casos quien denuncia es el varón, que pertenecía al común, y pretendía casarse con una india principal.

En 1700 un indio macegual de Coyotepeque, del obispado de Oaxaca, se siente engañado porque había recibido promesa de matrimonio de Isabel María Ambrosio india natural y principal del mismo pueblo ${ }^{25}$. El

nio entre Paulino Angulo y María Celedonia Pimentel por haber afinidad ya que esta llevó a bautizar un hijo que Francisca Pimentel tuvo con el referido Paulino Angulo, Tlaxiaco, 1780; Leg. 19, exp. 6, Libro donde se asientan las actas matrimoniales del año de 1745 de Santa Catarina Ixtepeji. Ciudad de Antequera, Santa Catarina Ixtepeli 1745, 27 ff.; exp. 7, Antonio Martín Vicente, indio natural de San Lucas Teitipac solicita que se agilicen las diligencias para contraer matrimonio con Rosa López, San Lucas Teitipac, 1766, 2 ff.; exp. 10, Maria Gertrudis Palacios y Ramón Bustos ambos viudos solicitan permiso para contraer matrimonio, Ciudad de Antequera, 1780, $23 \mathrm{ff}$.

23. AEOx, matrimonios, 1797. Vid también AEOx, Obispado de Oaxaca, Caja Anexo 3, sin numerar, 1757, Diligencias llevadas a cabo ante el provisor sobre la pretensión de Juan de los Santos mulato para contraer matrimonio con María Manuela Calderón, castiza.

24. AEOx, Fondo obispado de Oaxaca, Sección curia de justicia, asuntos criminales, leg.2, exp. 14, Paula María solicita justicia al señor provisor ya que el cura de su pueblo, San Lucas Teitipaque, Manuel Joseph Calvo la obliga a casarse con Pedro González, 1780 (incompleto).

25. AGN Instituciones coloniales, Regio patronato, matrimonios, Vol. 154, exp. 1. La india principal otorga poderes ilimitados a un cacique y principal de la localidad 
agraviado presenta la queja ante el Tribunal del Obispado de Oaxaca y, tras la sentencia contraria a su petición, apela dicha sentencia ante el juzgado metropolitano. Para ser un macegual contó con medios y conocimientos, además de arrestos, para enfrentarse con una familia de principales y llegar hasta el metropolitano.

La defensa por ambas partes va a girar en torno a tres aspectos: la fuerza de obligatoriedad de la promesa de matrimonio, la libertad necesaria para que el matrimonio sea válido, y la necesidad del consentimiento paterno por parte de la mujer y más en caso de diferencia de «calidades», aspecto en el que inciden los padres.

El denunciante considera que la promesa obliga:

pues si la palabra esta probada como lo esta en los autos, con los adminiculos de la devoción, comunicación secreta, trato en lugares escondidos, protesta de impedirse uno a otro qualquiera casamiento, y todo esto aprobado por el citado auto de veintitrés de julio es agravio no obligarla a su cumplimiento ${ }^{26}$.

Sin embargo, a lo largo del proceso se demuestra que, aun siendo importante, la promesa de matrimonio no suplía la libertad de los contrayentes; la Iglesia se oponía a obligar a casarse por haber hecho promesa, si cambiaba la voluntad.

El procurador de la Audiencia que defiende a Isabel María, insiste en dos aspectos: la primacía de la libertad y la opinión de los padres. Sostiene que aunque hubiere esponsales juradas (que en este caso no las había) es opinión común que si una parte se resiste, no se obligue a contraer matrimonio ${ }^{27}$. Respecto al consentimiento paterno, distingue

para que le represente y defienda en México. El principal que recibe el poder lo entrega a su vez al Notario del arzobispado para que se encargue de todo. Todo el razonamiento judicial es propio de la legislación canónica. Se sitúa a la mujer como fácil para el engaño, necesidad de consentimiento paterno para matrimonio, etcétera. La parte contraria defiende que las mismas obligaciones en el juramento y ante la ley tiene el varón y la hembra. La única referencia concreta al derecho es Trento.

26. AGN Instituciones coloniales, Regio patronato, matrimonios, Vol. 154, exp. 1, fol. $35 \mathrm{v}^{\circ}$.

27. AGN Instituciones coloniales, Regio patronato, matrimonios, Vol. 154, exp. 1. Fol. 43v. Libertad imprescindible para casarse: «y declaro no tener lugar lo pedido por el dicho Bartholome Garcia, por su ultimo escripto serca de que se le compeliesse por todo rigor de derecho a que le cumpliesse dicha palabra, por ser expressa excepcion de 
entre derechos antiguos ${ }^{28}$ "que requerían de essencia el paterno ascenso", y los modernos que lo "permiten y atienden de decencia congruentemente...», especialmente si existe «disparidad social». Esto es, la oposición paterna presente en este caso, queda reforzada por la diferencia de calidades entre ambos contrayentes.

El juez metropolitano, al final del proceso, tras indicar que se animase a Isabel María a cumplir su palabra de matrimonio, resuelve que si esta se mantenía en su negativa, no se le debía obligar y por tanto quedaba libre de la palabra dada. Es decir, la promesa tenía bastante fuerza y lo que inclina la balanza para librarle de la misma, no es el consentimiento paterno sino la libertad necesaria para que exista el matrimonio.

Un resultado más llamativo alcanzó un caso similar resuelto en Cholula. Un indio macegual defendió su derecho a casarse en contra de la oposición paterna de la otra parte; se apoyaba en la promesa recibida y en la decisión libre de la otra parte a contraer matrimonio. El denunciante aseguró «tener tratado» ${ }^{29}$ contraer matrimonio con Leonarda María Josefa Atlauten, india principal, doncella de diez y siete años, y pidió al juez eclesiástico que confirmada su libertad «sin apremio se extraiga de su casa y se ponga en depósito donde nuevamente reciba su declaración». Pide que se compruebe su voluntad de contraer o no matrimonio, sin ningún tipo de apremio, de manera que quede patente ante la iglesia su libertad.

Está utilizando la legislación matrimonial por la cual la Iglesia primaba ante todo la libertad de los contrayentes, a pesar de la costumbre del consentimiento paterno, y si faltaba la libertad no existía matrimonio.

el canonico, que en semejantes casos mas ainas se amoneste al renuente y no que se compela por los daños que se pueden seguir, y el mayor que es serca de la libertad esencialmente nesesaria para contraer, la qual es incompatible con el acto de compulsion o apremio, en cuya atencion infirio dicho señor jues a la consienscia de dicha Isabel Ambrosio, para que siguiendo el recto dictamen de ella pueda casar por palabras de presente que hagan verdadero matrimonio, segun y en la forma que dispone el santo consilio de Trento, con Joseph de Aquino, y para que ocurriesse a su proprio parocho se le diesse testimonio de dicho autto».

28. Estos derechos antiguos bien podrían referirse a las costumbres prehispánicas por las que los padres decidían el matrimonio.

29. Archivo parroquial de San Pedro Cholula, Fondo informaciones matrimoniales, Información matrimonial de Andrés de Jesús Teocuitlahua, 17 de abril de 1784, citado en González Hermosillo, pp. 126-128. 
El padre presenta como fundamento de su oposición «una novísima cédula» expedida y publicada por ambas jurisdicciones eclesiástica y secular que prohibía matrimonios con desigualdad de sangre. Así lo decretó dicha autoridad episcopal el 23 de abril de 1784.

La citada cédula, que no hace ninguna referencia a la población indígena, prohíbe los contratos de esponsales o matrimonio de «menores» de veinticinco años ${ }^{30}$ sin el consentimiento paterno o de los familiares más cercanos ${ }^{31}$. Establece que de celebrarse el matrimonio sin ese consentimiento, no quedaría anulado (porque no es potestad secular) pero se le negarían todas las consecuencias civiles, como son el derecho a dote, herencia, etcétera. En cuanto a las calidades, la cedula concreta y recuerda algo muy importante: «Que los indios caciques por su nobleza se consideren en las clases de los españoles distinguidos para todo lo prevenido en la Real pragmática» (estamos en el último tercio del siglo XVIII) ${ }^{32}$.

Puede parecer natural que en el siglo XVIII o en el XVII los indios cumplan las formalidades para el matrimonio, pero no lo es que utilicen legislación canónica y secular para oponerse a un matrimonio desigual; que estuviera arraigada la promesa de matrimonio y que, como en este caso, se opusieran a ella por motivos sociales. Defienden preeminencias y derechos que forman parte de la sociedad criolla, no específicamente india.

En este caso el indio macegual logró su propósito y se casó con su prometida.

Encontramos otros casos más ordinarios como petición de permisos por consanguinidad, o por casarse español con india, como la

30. Sorpende esta aseveración cuando comunmente se admitía que la edad válida y lícita para el matrimonio eran los catorce años: «Por derecho eclesiástico se requiere que los contrayentes sean púberes, cap. 6. cap. 10. cap. 11. h.t. S. Thom. in 4. dist. 36. q. un. art. 5. Sánchez de Matrim. lib. 7. disp. 104. n. 9. González in cap. 2. h.t. n. 7. et comm. DD. Lo mismo es por el derecho civil. Princ. Instit. de Nuptis. Y por el derecho español. L. 6. tit. 1. p. 4. Allí dice: Mas para casamiento facer, ha menester, que el varon sea de edad de catorce años, e la muger de doce» (Murillo Velarde, 2008, Libro IV, Tit. II, sobre los esponsales de los impúberes).

31. Archivo de la Biblioteca Francisco de Burgoa, Fondo Luís Castañeda Guzmán, Libro de cordilleras del obispo Joseph de Ortigosa, ff. $49 \mathrm{r}^{\circ}-72 \mathrm{r}^{\circ}$.

32. El asunto llegó al juzgado del provisor y vicario general del obispado de Puebla de los Ángeles ante el cual el indio noble intentó detener las amonestaciones que restaban. 
«solicitud de licencia para contraer matrimonio entre el sargento mayor del Batallón de Oaxaca, Luis de Zárate y María Josefa Nieto, descendiente del emperador Moctezuma a fines del XVIII» ${ }^{33}$.

Me parece que con estos casos he presentado algunos ejemplos de asimilación de pautas matrimoniales y sociales.

Vayamos al segundo ámbito en el que verificar la apropiación de costumbres castellanas:

\section{LA PROBANZA DE SANGRE Y MÉRITOS}

Las probanzas de sangre se pueden entender de forma amplia ${ }^{34}$ como la acreditación del prestigio y calidad social de una persona, e incluso como un documento de méritos y servicios. En principio se tramitaban «ante la real justicia ordinaria» ${ }^{35}$ y no ante la eclesiástica con la excepción del Santo Oficio ${ }^{36}$. Pero los alcaldes mayores en las tramitaciones de probanzas solicitaban a su vez al párroco las certificaciones o copias de los registros de bautizo con las filiaciones, etcétera. Además, «los vicarios eclesiásticos otorgaban información semejante en los disensos paternos para impedir los matrimonios desiguales y recibían los autos correspondientes a la prosecución o desistimiento del matrimonio» ${ }^{37}$. Por último, por diferentes motivos hubo ocasiones en que los indios solicitaron esa información en el obispado, o la presentaron por requerirlo las autoridades eclesiásticas.

Los informes de este tipo sobre indios encontrados en los archivos eclesiásticos no hacen referencia a la pureza religiosa, limpia de heterodoxos - dato que sí recogen las probanzas de los indios que accedían a la universidad de $\mathrm{México}^{38}$-, sino a la limpieza étnica, racial, sobre

33. AGN Instituciones coloniales, Regio patronato, matrimonios (069), volumen 8, exp. 2, fojas 26-87. Estamos en 1798.

34. La definición más genuina de expediente de limpieza de sangre es: «requisito legal impuesto por la autoridad para el desempeño de ciertos cargos públicos, empleos, oficios o dignidades del Estado y de la Iglesia» (Lira Montt, 1997, p. 32).

35. Lira Montt, 1997, p. 42.

36. La inquisición tramitaba ella misma los expedientes de limpieza de sangre, exigiendo además una información mucho más exhaustiva.

37. Castillo Palma, 1996, pp. 142-143.

38. Menegus, 1989; Menegus y Salvador, 2006; Lavrin, 1999; Zaballa Beascoechea, 2000. 
todo con referencia a aquellas consideradas de baja calidad como la negra y las mezclas a partir de ella ${ }^{39}$; así como su procedencia noble.

A este respecto, Norma Angélica Castillo Palma ${ }^{40}$ indica -refiriéndose a Cholula - que las probanzas de pureza de sangre las solicitaban a los alcaldes mayores y estos solicitaban al párroco las certificaciones o copias de los registros de bautizo con las filiaciones, etcétera, y añade:

los vicarios eclesiásticos otorgaban información semejante en los disensos paternos para impedir los matrimonios desiguales y recibían los autos correspondientes a la prosecución o desistimiento del matrimonio.

Será, en efecto, en los asuntos matrimoniales donde encontremos con más frecuencia la referencia a esa información de limpieza de sangre o presentación de genealogías ${ }^{41}$. También las hemos encontrado en la fundación de una capellanía por un matrimonio de indios principales.

Este expediente de fundación de capellanía ${ }^{42}$, contiene varias probanzas de limpieza de sangre y ofrece también los criterios de prestigio entre los indígenas principales en el siglo XVIII.

Los fundadores son un matrimonio de principales, con muchas propiedades y genealogía importante por ambas partes. Su escala de valores quedó reflejada en las condiciones que impusieron a los posibles candidatos. Establecieron que los primeros en ocupar la capellanía serían sus hijos y parientes, «y por su defecto a otros caciques del mismo obispado, estableciendo por regla general que solo se entiendan llamados indios puros, nobles hijos legítimos y honestos y virtuosos que es toda la ley que debe dirigir la aplicación de este beneficio» ${ }^{43}$.

39. Los mestizos, que también serán orillados, se aceptan con mucha más facilidad que cualquier mezcla con negro o mulato.

40. Castillo Palma, 1996, p. 142-143.

41. En algunos casos los caciques principales para mostrar su dignidad requieren la inclusión de la cédula de Carlos II, de 22 de marzo de 1697, pues «Por medio de ella la monarquía reconoce una distinción entre los indios principales o caciques, equiparados legalmente a los hidalgos castellanos, y los indios menos principales o tributarios, en quienes concurren la puridad de sangre, como descendientes de la gentilidad, no mezclados con sectas reprobadas, y merecedores en derecho de todas las prerrogativas, dignidades y honras que gozan en España los limpios de sangre, que llaman del estado general» (Lira Montt, 1997, p. 45).

42. AGN Bienes Nacionales (014), Vol. 553, exp. 8 año, 1722.

43. AGN Bienes Nacionales (014), Vol. 553, exp. 8 año, 1722, fol 197v. 
Es decir, limpieza de sangre, nobleza —estatus social—y virtud. Respecto a la nobleza que se requiere se aclara que

quando los fundadores se llaman casiques y llaman a otros casiques, no hablan de los que son verdaderamente tales en el sentido rigorista de la ley y según los había en el siglo de la conquista quando esta se expidió, sino solo a los que hoy se llaman casiques por descendientes de aquellos, aunque no estén en el goze de los derechos del casicazgo, en cuanto a exigir tributos y vasallos.

El expediente contiene las probanzas de limpieza y nobleza de tres candidatos a la capellanía. El primer candidato probó ${ }^{44}$, en efecto, ser descendiente de caciques, incluyó la real cédula arriba citada, y presentó, al estilo castellano, los méritos de sus antepasados:

Don Julián Carrasco casique originario, Hijo del Cacique D. Julián Carrasco que recibió el Santo Evangelio y con el cargo de capitán militó bajo el mando de el Excelentísimo Sr. D. Hernando Cortés Marqués del Valle en la conquista y pacificación que expresa.

El segundo candidato quedó excluido porque algunos testigos demostraron que su abuela paterna «fue de calidad parda» y porque su padre era «tozinero». Estos dos datos, sangre manchada y oficio impropio a la calidad de noble, serían decisivos para ser rechazado ${ }^{45}$.

El tercero en disputar la capellanía también fue excluido «pues aunque alegó que es indio puro y de los que hoy se llaman principales que ejercen los cargos de su república: también es cierto que no ha probado descender de caciques y lo que es más (....) ha confesado que su padre es tributario». Se le concedió la capellanía a Don Julián Carrasco, el primer candidato.

44. AGN Bienes Nacionales (014), Vol. 553, exp. 8, año 1722, fol. 63, «probanza ad perpetuam rei memoriam».

45. Por gentileza del Dr. Felipe Castro aporto dos referencias del ámbito de Pátzcuaro, donde se muestra la exigencia de oficio noble para los cargos indígenas importantes hasta finales del siglo XVI y cómo a mediados del XVIII se relaja esta exigencia: Archivo Histórico Municipal de Páztcuaro, AHMP, caja 132-1, 2 f : Los principales y común de Pátzcuaro sobre que se guarde el decreto para que no se elija como gobernador a ninguno de oficio mecánico, 1674; AHMP, caja 34, carpeta 2, 1 f., Aprobación de la elección como gobernador de Pátzcuaro de Miguel Huacuja, 1746 y AHMP, caja 132-4, 12 f. 
En otras probanzas, se presentan como méritos el haber ejercido cargos en el cabildo y relacionados con la Iglesia, además de la ascendencia de sangre noble indígena. Así un cacique indio de Cholula probó su calidad por los cargos ejercidos por antepasados y por los que desempeñó él mismo en la iglesia como fiscal mayor, en el cabildo de indios, como escribano - el mérito de saber escribir-y alcalde y porque tenía un pariente cercano presbítero, pues para serlo se debía probar la nobleza de origen además de la formación, calidad y virtudes ${ }^{46}$.

En algunos documentos se puntualiza que los cargos importantes como alcalde o gobernador sólo se concedían a los caciques y principales. Esta aclaración es importante porque demuestra la continuidad en época colonial — como mínimo hasta fines del siglo XVII- de las élites de poder prehispánicas, al menos en algunas regiones y pueblos.

En este sentido discurre un expediente de información de cacicazgo que se siguió ante el Tribunal Eclesiástico del Obispado de Chiapas. Se trata de la «Información que comprueba el cacicazgo y distingue la prosapia de D. Domingo Santa María Noti Quiñones, Guerra y Guevara, de Chiapa la Real» ${ }^{47}$. Es un documento del siglo XVIII en el que el interesado insertó junto a la petición del certificado, el interrogatorio que deseaba se realizara a los testigos, de forma que quedara patente su capacidad y prestigio: legitimidad, descendencia de caci-

46. Archivo parroquial de San Pedro Cholula, Fondo informaciones matrimoniales, Información matrimonial de Andrés de Jesús Teocuitlahua, 17 de abril de 1784, citado en González Hermosillo, 1996, p. 126: «soy puramente indio y uno de los principales de dicha ciudad, en cuya virtud he servido en la Santa Iglesia Parroquial con el empleo de fiscal mayor por seis años, en el ayuntamiento del cabildo de su escribano cuatro años, y el empleo honorífico que ahora estoy sirviendo [alcalde ordinario de primer voto del Ayuntamiento de la nobilísima ciudad de Cholula]. Es pública y notoria mi descendencia de indios principales y nobles, acreditado que no falta de ellos testimonio con tener un primo bermano presbitero, que lo es el bachiller don Juan de Atlauten, teniente de cura del partido de Tuxtepec» (Cholula). Son muy similares las probanzas que he localizado firmadas por el corregidor. Por ejemplo, Biblioteca Burgoa, Fondo Castañeda, 1303 a/41, Información de nobleza dada por Pedro de Chaves Casique del Pueblo de Santa Cruz. Lo que se pregunta a los testigos es si es cacique e hijo de caciques; si estaban exentos de pagar tributos y de servicios personales; obtuvieron cargos de gobernador, alcalde de aquella república; que eran estimados por los ministros de doctrina y el alcalde mayor...

47. Archivo Histórico Diocesano de San Cristóbal de las Casas, Chiapas, III, serie I, 1, 1772 . 
ques; cargos que «solo se daban a los caciques» y que fueron ejercidos por sus antepasados ${ }^{48}$, etcétera.

En el expediente, además de testificaciones de indios principales del pueblo de Chiapa, se incluyen las de dos dominicos y un cura párroco que se extendieron en alabanzas al interesado y a su familia tanto por su ascendencia nobiliaria como por sus obras de caridad, enseñanza de la doctrina y servicios a su Majestad.

Limpieza de sangre: pureza de sangre sin mezcla de mulatos $u$ otras castas, linaje de caciques, ejercicio de cargos de república, buena fama y buenas costumbres. Calidad, fama o reputación social y méritos y servicios... valores similares a los defendidos por los criollos, no porque piensen como ellos sino porque comparten la misma base de creencias religiosas y de derecho, dentro de la diversidad de mentalidades y culturas.

\section{REFLEXIONES FINALES}

Quizá lo más llamativo tras esta primera revisión de la presencia y actuación de los indígenas en los foros de justicia eclesiástica, es que estuvieron presentes en el siglo XVI —-fueron, como se ha dicho, aprendices precoces-, y los seguimos encontrando en el XVII y hasta finales del XVIII. Es decir, tuvieron éxito ante la justicia eclesiástica, manejaron bien todos sus resortes y fueron actores habituales en estos foros.

Aunque se trata de una revisión que debe ser completada, se puede adelantar que los indios conocían la legislación canónica y las posibilidades que esta les ofrecía en relación con la justicia secular. Emplearon tanto la apelación a la instancia eclesiástica superior, como el cambio de la jurisdicción eclesiástica a la secular, para lograr sus objetivos. En este sentido utilizaron, por ejemplo, el derecho de amparo o el recurso de fuerza.

Dentro de la jurisdicción eclesiástica acudieron, en cada caso, al aspecto legal que más efecto podía tener ante sus jueces: la inmunidad eclesiástica, el mal ejemplo de un fiscal, o la falta de libertad en un matrimonio.

48. Uno de los testigos asegura que «habían sido los mas, alcaldes de primer voto y gobernadores deste dicho pueblo». Vid. Romero Frizzi, 1996. 
En segundo lugar respecto al matrimonio, se puede decir, que una parte importante de la población tenía asumidas la primacía de la libertad, pero también utilizaron en su favor la fuerza que tenía en la sociedad colonial la promesa de matrimonio, o la legislación secular y eclesiástica sobre el consentimiento paterno. La legislación para evitar matrimonios desiguales reforzaba su propia política matrimonial para preservar los linajes y la élite indígena, de la misma forma que actuaban las élites criollas.

Por último, los criterios de prestigio y nobleza varían en algunos puntos, amoldándose al nuevo orden, al tiempo que buscaron conservar sus linajes.

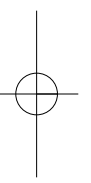




\section{FUENTES}

Archivo General de la Nación, México ( $A G N$ )

AGN, Bienes nacionales. Vol. 149, expediente 25, año 1791.

AGN, Bienes Nacionales. Vol. 553, expediente 8, año 1722.

AGN, Indios, Vol. 20, expediente 125, año 1656.

AGN, Instituciones coloniales, Regio patronato, matrimonios, Vol. 8, expediente 2, ff. 26-87.

AGN, Instituciones coloniales, Regio patronato, matrimonios, Vol. 154, exp. 1.

AGN, Indiferente virreinal, Caja 1531, expediente 8, año de 1753.

Archivo del Estado de Oaxaca (AEOx)

AEOx, Sección curia de justicia, Serie Asuntos criminales, Leg. 1, Exp. 23. Hipólito de los Santos y Pascual de la Vega contra Pascual Pérez, alcalde que fue de ese lugar por arbitrariedad a la inmunidad eclesiástica, 1752.

AEOx: Sección curia de justicia, Serie Asuntos criminales, Leg. 1, Exp. 20 y 21. El pueblo de Yagago contra Miguel de los Ángeles Alguacil mayor, fiscal de doctrina sobre los capítulos que se expresan, 1751.

AEOx, Fondo obispado de Oaxaca, Sección curia de justicia, asuntos criminales, Leg. 2, exp. 14. Paula María solicita justicia al señor provisor ya que el cura de su pueblo, San Lucas Teitipaque, Manuel Joseph Calvo la obliga a casarse con Pedro González, 1780 (incompleto).

AEOx, Fondo Obispado de Oaxaca, Curia de gobierno y administrativa, Serie matrimonios, bautizos y defunciones; Exp. 15. Diligencias seguidas para negar el permiso de realizar matrimonio entre Paulino Angulo y María Celedonia Pimentel por haber afinidad ya que esta llevó a bautizar un hijo que francisca Pimentel tuvo con el referido Paulino Angulo, Tlaxiaco, 1780.

AEOx, Fondo Obispado de Oaxaca, Curia de gobierno y administrativa, Serie matrimonios, Leg. 19.

Exp. 6, libro donde se asientan las actas matrimoniales del año de 1745 de Santa Catarina Ixtepeji. Ciudad de Antequera, Santa Catarina Ixtepeli, $1745,27 \mathrm{ff}$.

Exp. 7, Antonio Martín Vicente, indio natural de San Lucas Teitipac solicita que se agilicen las diligencias para contraer matrimonio con Rosa López, San Lucas Teitipac, 1766, 2 ff.

Exp. 10, María Gertrudis Palacios y Ramón Bustos, ambos viudos, solicitan permiso para contraer matrimonio, Ciudad de Antequera, 1780, $23 \mathrm{ff}$. 
AEOx, Obispado de Oaxaca, Caja Anexo 3, sin numerar, 1757. Diligencias llevadas a cabo ante el Provisor sobre la pretensión de Juan de los Santos, mulato, para contraer matrimonio con María Manuela Calderón, castiza.

Archivo Histórico Diocesano de San Cristóbal de las Casas

Chiapas, III, serie I, 1, 1772.

Biblioteca Francisco de Burgoa, Fondo Luis Castañeda Guzmán, Oaxaca

Libro de cordilleras del obispo Joseph de Ortigosa, ff. 49ro-72 $\mathrm{r}^{\mathrm{o}}$ (sin clasificar).

\section{BIBLIOGRAFÍA}

ARAmoni CALDERÓn, Dolores, «Iglesia, cultura y represión entre los zoques de Chiapas en el siglo XVII», en Ramos, G.; Urbano, H. (comps.), Catolicismo y extirpación de idolatrías. Siglos XVI-XVIII, Cuzco, Centro de Estudios Regionales Andinos «Bartolomé de las Casas», 1993, pp. 367-387.

BALSALOBRE, Gonzalo de, «Relación de las idolatrías, supersticiones y abusos en general de los naturales del Obispado de Oaxaca», en Hernando Ruiz de Alarcón, Dr. Pedro Sánchez Aguilar, Gonzalo de Balsalobre, Tratado de las idolatrias, supersticiones, dioses, ritos, hechicerías y otras costumbres gentilicias de las razas aborígenes de México, notas comentarios y un estudio de Francisco del Paso y Troncoso, México, Ediciones Fuente Cultural, 1948-1952 [la primera edición es del Museo Nacional 1892].

Castillo Palma, Norma Angélica, «El estudio de la familia y del mestizaje a través de las fuentes eclesiásticas: el caso del archivo parroquial de San Pedro Cholula», en Connaughton, Brian F.; Lira, Andrés (coords.), Las fuentes eclesiásticas para la historia social de México, México, Universidad Autónoma Metropolitana-Instituto Dr. José María Luis Mora, 1996, pp. 133-164.

Concilios provinciales primero y segundo, celebrados en la muy noble y muy leal ciudad de México, presidiendo el illmo. y rmo. señor D. Fr. Alonso de Montúfar, en los años de 1555 y 1565. Dalos a la luz el ill.mo Sr. D. Francisco Antonio Lorenzana, arzobispo de esta santa metropolitana iglesia [...], En México, en la imprenta de el Superior Gobierno, de el Br. D. Joseph Antonio de Hogal, 1769

Cruz, Patricia; Gil, Francisco; Rojas, José Luís, «Soy descendiente de Don Juan Istolinque y Guzmán. El cacicazgo de Coyoacán en el siglo XVIII», en Relaciones, Colegio de Michoacán, 109 (2007), pp. 51-73. 
Dougnac Rodríguez, Antonio, Manual de Historia del derecho indiano, México, McGraw-Hill, UNAM, $1998^{2}$.

Duve, Thomas, «La condición jurídica del indio y su condición como persona miserabilis en el Derecho Indiano», en Losano, Mario (ed.), Un giudice e due leggi. Pluralismo normativo e conflitti agrari in Sud America, Milano, Giuffrè, 2004, pp. 3-33.

Duviols, Pierre, Cultura andina y represión: procesos y visitas de idolatrias y hechicerias, Cajatambo, siglo XVII, Cuzco, Centro de Estudios Rurales Andinos «Bartolomé de las Casas», 1986.

- Procesos y visitas de idolatrías. Cajatambo, siglo XVII, Lima, Instituto Francés de Estudios Andinos, Pontificia Universidad Católica del Perú, 2003.

Feria, Pedro de, «Revelación sobre la reincidencia en sus idolatrías de los indios de Chiapa después de treinta años de cristianos», en Francisco del Paso y Troncoso, Tratado de las idolatrias, supersticiones, dioses, ritos, hechicerias y otras costumbres gentílicas de las razas aborígenes de México, México, Fuente Cultural, 1982, vol. 1.

GAREIS, Iris, «Repression and cultural change: the 'Extirpation of Idolatry' in colonial Peru», en Griffiths, Nicholas; Cervantes, Fernando (eds.), Spiritual Encounters. Interactions between Christianity and native religions in colonial America, Birmingham, The University of Birmingham Press, 1999, pp. 230-254.

GÓmEz GARcía, Lidia E., «Las fiscalías en la ciudad de los Ángeles, siglo XVII», en Castro Gutiérrez, Felipe (ed.), Los indios y las ciudades de Nueva España, México, Universidad Nacional Autónoma de México (en prensa).

GonZÁlez Hermosillo, Francisco, «Las fuentes eclesiásticas para el estudio de las comunidades indígenas: el caso de Cholula en el siglo XVIII», en Connaughton, Brian F.; Lira, Andrés (coords.), Las fuentes eclesiásticas para la historia social de México, México, Universidad Autónoma Metropolitana-Instituto Dr. José María Luis Mora, 1996, pp. 115-132.

GRIfFITHS, Nicholas, The Cross and the Serpent: Religious Repression and Resurgence in Colonial Peru, Norman and London, University of Oklahoma Press, 1996.

HILlerkuss, Thomas, Colima entre 1540 y 1575. La formación de una sociedad en la periferia del virreinato, Colima, Archivo Histórico del Municipio de Colima, serie Pretextos, $\mathrm{N}^{\circ} 25,2001 \mathrm{a}$.

- Diccionario biográfico del occidente novobispano. Siglo XVI, Vol. 2. D-G, Zacatecas, Universidad Autónoma de Zacatecas-Centro de Docencia Superior, 2001b. 
Kellogg, Susan, Weaving the Past: A History of Latin America's Indigenous Women from the Prebispanic Period to the Present, Oxford, Oxford University Press, 2005.

KLOR DE AlvA, J. Jorge, «Colonizing souls: The failure of the Indian Inquisition and the rise of penitential discipline», en Cultural encounters: The impact of the Inquisition in Spain and the New World, Perry, Mary E. (ed.)., Berkeley u.a., Univ. of California Press, 1991, pp. 3-22.

LATASA, Pilar, "La celebración del matrimonio en el virreinato peruano: disposiciones sinodales de Charcas y Lima (1570-1613)», en Arellano, Ignacio; Usunáriz, Jesús M. ${ }^{a}$ (eds.), El matrimonio en Europa y el mundo hispánico. Siglos XVI y XVII, Madrid, 2005, pp. 237-256.

LATASA VASAllo, Pilar, «Publicidad y libertad en el matrimonio: autoridad paterna y dispensa de amonestaciones en Lima, 1600-1650», en Usunariz, J. M.a; García Bourrellier, R. (eds.), Padres e bijos ante el matrimonio: España y el Mundo Hispánico (siglos XVI-XVIII), Madrid, Visor Libros, 2008, pp. 53-67.

LAVRIN, Asunción, «Indian Brides of Christ: Creating New Spaces for Indigenous Women in New Spain», en Mexican Studies-Estudios Mexicanos, 1999.

LIRA, Andrés, «El indio como litigante en cincuenta años de Audiencia, 15311580», en Memoria del X Congreso del Instituto Internacional de Historia del Derecho Indiano, México, UNAM, 1995, T. I, pp. 765-782.

LiRA MONTT, Luis, «El estatuto de limpieza de sangre en el Derecho indiano», en XI Congreso del Instituto Internacional de Historia del Derecho Indiano. Buenos Aires 4 al 9 de septiembre de 1995. Actas y Estudios, Buenos Aires, Instituto de Investigaciones de Historia del Derecho, 1997, pp. 31-47.

MARgAdANT, Guillermo Floris, «Del matrimonio prebispánico al matrimonio cristiano», VI Anuario Histórico-Jurídico Ecuatoriano, Quito, 1980, pp. 515-528.

Menegus, Margarita, «La real y Pontificia Universidad de México y los expedientes de limpieza de sangre», en Albiñana, Salvador (ed.), Claustros y estudiantes: Congreso Internacional de Historia de las universidades americanas y españolas en la edad moderna, Valencia, Universidad de Valencia, 1989.

Menegus, Margarita y Aguirre, Salvador, Los indios, el sacerdocio y la Universidad en Nueva España. Siglos XVI-XVIII, México, CESU-Plaza y Valdés, 2006.

Murillo Velarde, Pedro, Curso de derecho canónico hispano e indiano, El Colegio de Michoacán (traducción Alberto Carrillo Cázares), Zamora Michoacán, El Colegio de Michoacán, 2008. 
Romero Frizzi, M. ${ }^{a}$ de los Ángeles, El Sol y la Cruz. Los pueblos indios de Oaxaca Colonial, México D. F., Centro de Investigaciones y Estudios Superiores de Antropología Social, Instituto Nacional Indigenista, 1996.

TAVAREZ, David, «Idolatry as an ontological question: Native consciousness and juridical proof in colonial Mexico", Journal of Early Modern History 6, 2 (2002), pp. 114-139.

Traslosheros, Jorge E., Iglesia, Justicia y Sociedad en la Nueva España: La Audiencia del Arzobispado de México, 1528-1668, México, Editoral Porrúa \& Universidad Iberoamericana, 2004.

- «Orden judicial y herencia medieval en la Nueva España», en Historia Mexicana, LV: 4 (2006), pp. 1105-1138.

Zaballa Beascoechea, Ana de, «Los Afromestizos en la Real Universidad de México», Iberoamericana XXII (2000), pp. 83-99 (Tokio, Japón). 


\section{Sobre los autores}

Alberto Carrillo Cázares, es profesor investigador titular C del Centro de Estudios de las Tradiciones, El Colegio de Michoacán A.C. (1991-2009). En los últimos años ha dirigido tres importantes proyectos de edición y traducción sobre la obra de Pedro Murillo Velarde S. J., Curso de Derecho Canónico Hispano e Indiano publicado en 2005 y los Manuscritos del Concilio III Provincial Mexicano (1585), publicados en 2006 y 2007.

<acarrillo1923@hotmail.com>

JoHn CHARLES, es profesor de Literatura Hispanoamericana en el Departamento de Español y Portugués en la Universidad de Tulane, Nueva Orleáns, EE. UU. Autor de estudios sobre Guaman Poma, la Iglesia en los Andes y la población indígena. Entre sus publicaciones cabe mencionar Allies at Odds: The Andean Church and its Indigenous Agents, 1583-1671 (Albuquerque, University of New Mexico Press, 2010), que examina el papel de los intermediarios nativos en el proceso de evangelización en el virreinato del Perú.

$<$ jcharles@tulane.edu>

Macarena Cordero Fernández, es profesora de Historia Colonial de la Universidad Adolfo Ibáñez (Santiago de Chile). Doctora en Historia por la Pontificia Universidad Católica de Chile. Dedica su investigación a las Visitas pastorales en el virreinato del Perú.

<maca.cordero@yahoo.es> 
Thomas Duve, es director del Instituto Max Planck de Historia del Derecho Europeo (desde 2009), profesor de Historia del Derecho Canónico en la Pontificia Universidad Católica Argentina, Buenos Aires. Ha dedicado sus últimos trabajos a estudios sobre el derecho canónico indiano.

<duve@mpier.uni-frankfurt.de>

Juan Carlos García Cabrera, es historiador, investigador de la Universidad de San Martín de Porres, Lima. Es autor de varios estudios sobre Historia Eclesiástica del Perú, en particular sobre el fenómeno de la extirpación de la idolatría y el proceso de evangelización en el Arzobispado de Lima. Actualmente trabaja en la edición completa del corpus documental de procesos de idolatrías y hechicerías en el Arzobispado de Lima, siglos XVII-XIX, diez volúmenes.

<jgcabrera@gmx.de>

Pedro M.Guibovich Pérez, es profesor de la Universidad Católica del Perú. Autor de estudios sobre historia colonial, en particular en relación con la educación, la iglesia y la Inquisición. Recientemente editó, en coautoría con Luis Eduardo Wuffarden, el libro Sociedad y gobierno episcopal. Las visitas del obispo Manuel de Mollinedo y Angulo, 1674-1687 (Lima, 2008). Prepara un libro sobre la censura inquisitorial de libros en el virreinato peruano entre 1756 y 1812 <pguibovich@pucp.edu.pe>

MAGNUS LUNDBERG, es profesor-investigador de Historia Eclesiástica y Misionología en la Facultad de Teología, Universidad de Uppsala, Suecia. La mayoría de sus publicaciones tratan temas de historia eclesiástica novohispana, siglos XVI y XVII. Entre sus publicaciones hay que destacar Unification and Conflict: The Church Politics of Alonso de Montúfar, Archbishop of Mexico, 1554-1572 (Uppsala 2002; versión castellana por El Colegio de Michoacán, 2009); y en prensa sobre las relaciones entre curas párrocos y los indígenas en la archidiócesis de México y diócesis de Puebla durante el siglo XVII: Between the Metropolitan and the Local: Parishes, Parishioners, and Parish Priests in SeventeenthCentury Mexico.

<magnus.lundberg@teol.uu.se> 
Luis Martínez Ferrer, es profesor de Historia de la Iglesia en la Universidad Pontificia de la Santa Cruz (Roma). Entre sus obras destacan: La Penitencia en la primera evangelización de México (15231585), Universidad Pontificia, México 1998; Fontes. Documenti fondamentali di storia della Chiesa, Cinisello Balsamo, (MI) 2005; Decretos del Concilio Tercero Provincial Mexicano, edición históricocrítica, El Colegio de Michoacán, Zamora, Michoacán, 2009.

$<$ lmartinez@pusc.it>

Ana de Zaballa Beascoechea, es profesora titular de Historia de América en la Universidad del País Vasco. Autora de estudios sobre milenarismo, mesianismo y religiosidad en la Nueva España. En la actualidad dedica su investigación a la relación Tribunales eclesiásticos y población indígena. Recientemente editó en colaboración con Jorge Traslosheros, Los indios ante los foros de justicia religiosa en la Hispanoamérica virreinal, Instituto de Investigaciones Históricas, Universidad Nacional Autónoma de México, México 2010.

<ana.dezaballa@ehu.es>

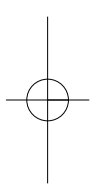


12-autores.qxd 11/09/2010 4:54 PEgina 242

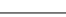

○
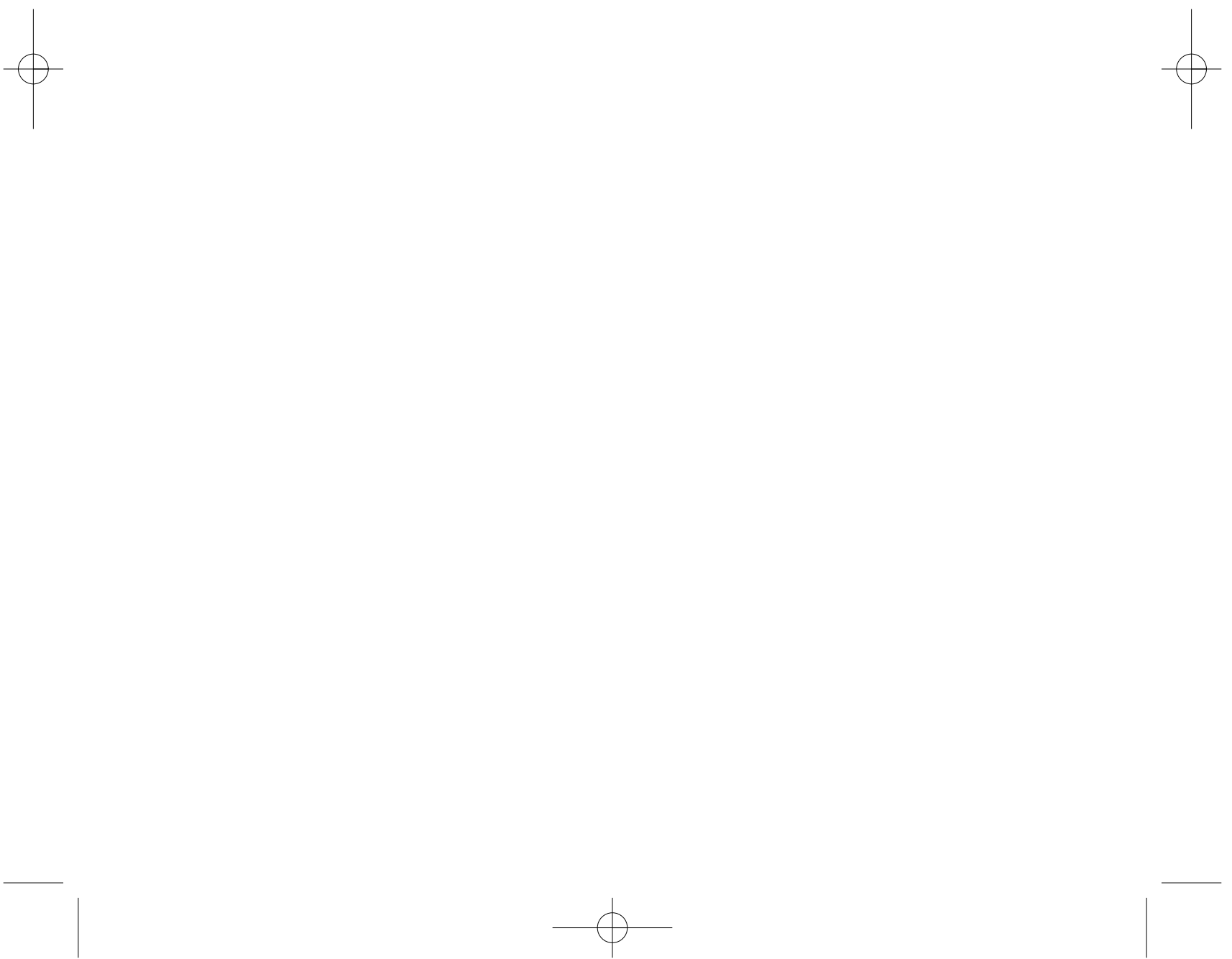